Perspective

\title{
Narrative Medicine Meets Planetary Health: Mindsets Matter in the Anthropocene
}

\author{
Susan L. Prescott ${ }^{1,2, *}$ and Alan C. Logan 3 (1) \\ 1 School of Medicine, University of Western Australia, Nedlands, WA 6009, Australia \\ 2 The ORIGINS Project, Telethon Kids Institute, Perth Children's Hospital, 15 Hospital Avenue, \\ Nedlands, WA 6009, Australia \\ 3 inVIVO Planetary Health, Research Group of the Worldwide Universities Network (WUN), 6010 Park Ave, \\ Suite \#4081, West New York, NJ 07093, USA; aclnd@cfs-fm.org \\ * Correspondence: susan.prescott@uwa.edu.au
}

Received: 27 December 2018; Accepted: 17 February 2019; Published: 20 February 2019

check for updates

\begin{abstract}
The emerging concept of planetary health-defined as the interdependent vitality of all natural and anthropogenic ecosystems (social, political, and otherwise)-emphasizes that the health of human civilization is intricately connected to the health of natural systems within the Earth's biosphere. In the clinical setting, narrative medicine underscores the importance of absorbing, reflecting upon, and responding to the narratives - the stories-conveyed by patients. Education and interventions using the tenets of narrative medicine have demonstrated value to both patient and provider. Given the grand interconnected challenges of our time-compounded by misinformation and quasi-scientific narratives propagated by the ideology of neoliberalism-we argue that the principles and practice of narrative medicine can be applied on a larger scale, one with planetary health in mind. The role of beliefs, expectations, and agency-mindsets-in the link between narrative and planetary health are emphasized. We use a story of our own to demonstrate that the biological buffering capacity in response to a fast-food meal does not sit on a level socioeconomic playing field. Patient, community, and global health narratives are melding with powerful narratives set by commercial entities. The success of planetary health as a new concept will be strengthened by attention to the ways in which storytelling can influence positive change. No less important is an understanding of the ways in which stories contribute to what ails person, place, and planet.
\end{abstract}

Keywords: planetary health; narrative medicine; neoliberalism; anthropogenic ecosystems; belief systems; values; noncommunicable diseases (NCDs); storytelling; clinical ecology; socioeconomic inequalities; social justice; exposome; ultraprocessed foods; green space

\section{Introduction}

"The patient has a story to tell; its theme is a lifeworld problem. In telling her story she is interrupted by the physician speaking in the voice of medicine"

Elliott G. Mishler, MD, The Discourse of Medicine, 1984 [1]

In the halls of academia, the word 'narrative' has long since been a fundamental currency within the arts and humanities. Only recently has it penetrated the highly-selective, semi-permeable lexicon of medical, physical, and biological sciences. For example, a simple PubMed search reveals that in 1980, the word, narrative, appears in the article title, abstract, and/or as a keyword only 14 times during the year. In the year, 2000, this number had increased to 248 articles; but this pales in comparison to 2018 — the word narrative appeared almost 4500 times. 
Etymologically, narrative derives from several Latin roots, including narrare, which means to relate or to tell, as well as gnarus, which translates as knowing or being acquainted with knowledge. Thus, narrative is the act of taking connected chain-links of knowledge, or events, and relating them to others; this relating of knowledge can be accomplished in many ways, most notably through the written word, oration, film, and creative imagery. Narrative, and its related construct of 'story', can also be found in a single piece of art.

Storytelling - the development and sharing of particular narrative messages—is considered a human universal; that is, storytelling is a feature of culture, society, language, behavior, and psyches the world over, without known exceptions [2]. Research involving the few remaining traditional hunter-gatherer groups-societies most reflective of our ancestral experience-demonstrates that storytelling has been an evolutionary asset. In particular, storytelling promotes cooperative social behavior, equity, and egalitarianism, and skilled storytellers are highly prized social partners within groups, even more so than effective foragers [3].

In particular, the stories we tell our children are of vital importance in promoting healthy mindsets during early life, when many value systems become established, including those related to empathy as well as social and environmental concern. As such, childhood can be viewed as a powerful window to achieve a frameshift in attitudes, which can influence the future 'health' trajectory of individuals, communities, and the wider environment. Our future increasingly depends on stories that promote a 'planetary health psyche' and translate into strong pro-health, pro-social, and pro-environmental attitudes and behaviors for future benefits at all scales (Figure 1).

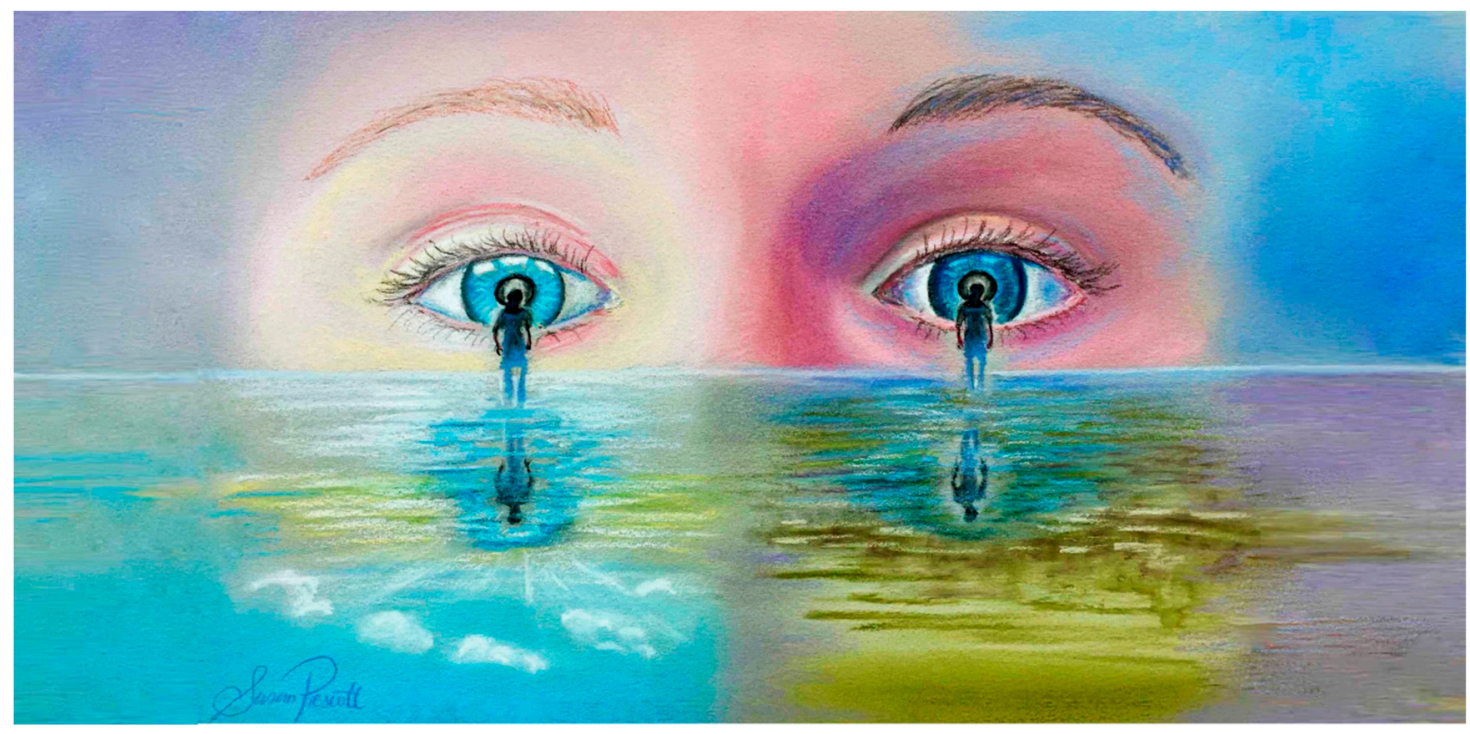

Figure 1. The stories we tell our children shape life-long attitudes to personal and planetary health, and the values that determine how they see themselves and the world around them. Our future depends on stories that promote a 'planetary health psyche' and translate into strong pro-health, pro-social, and pro-environmental attitudes and behaviors for future benefits at all scales.

Although it is argued here that 'narrative' has been hijacked in ways that compound global challenges-accelerating humanity into a strange era dubbed 'post-truth' [4] —when properly deployed within science and medicine, it can provide a pathway to trust at all scales. This is particularly important at a time when trust in institutions-including medicine-is declining [5,6]. As we argue here, thoughtful incorporation of narrative in science and medicine-not simply a trendy word, but all that narrative represents about the past, present, and future-is a sign of optimism in the face of pressing global challenges.

Planetary health is defined as the interdependent sustainable vitality of all natural and anthropogenic ecosystems (social, political, and otherwise) [7]. It is our contention that in the 
context of planetary health, narrative is no longer an 'add-on' within science and medicine. Rather, in the Anthropocene epoch-and its current era of widely-distributed misinformation-narrative is a necessity. Here, we describe how the lessons of narrative medicine can be applied to planetary health, positively influencing health and vitality at scales of person, place, and planet. Furthermore, since narrative cannot be separated from belief, a discussion of placebo science is central to the progression of narrative medicine.

\section{Roadmap to the Viewpoint}

The Challenges journal is committed to scholarly, interdisciplinary discourse related to the grand challenges of our time. Hence, the backdrop to our commentary includes the intertwined problems of non-communicable diseases (NCDs), climate change, environmental degradation, health inequalities, social injustices, the spread of ultra-processed foods, neoliberalism, over consumption, incivility, and related components of what has been described, collectively, as 'Anthropocene Syndrome' [8]. This syndrome is itself an 'illness' story, and it is from this vantage that we consider the importance of narrative and mindsets vis à vis the health of a person, place, and planet.

We begin by examining the emerging field of narrative medicine; this may be a relatively new term, but so long as there has been illness and healers intent on helping those afflicted, there has been narrative- knowledge is related to one person from the other. With the advancement of medical science, the knowledge relayed to the sufferer has been refined. This has been enormously beneficial to the person, and society-at-large. However, the personalized experience of illness-the sufferer's story - can be overlooked in the contemporary biomedical narrative, filled as it is with algorithms and discourse of decision trees based on someone else that was enrolled in a clinical trial. It is likely that the unidentified 'someone else' has had an entirely different lived experience and may be of a differing race, ethnicity, or socioeconomic position.

After discussing the merits and challenges associated with narrative medicine, we segue to an area we consider to be highly related (although rarely discussed in tandem), that of placebo studies. The role of belief systems, expectations, and agency-all of which contribute to illness narrative-is also as old as medicine itself. However, only recently has there been consensus concerning the depths to which the placebos-and more broadly, mindsets-penetrate all of healthcare. The biological bridge between narrative and placebo can be found in research, which demonstrates that both can have a profound influence on objectively-measured physiology.

Finally, we argue for a greater scientific understanding of narrative 'medicine' and mindsets at the larger scale. Scientists and other scholars are already in deep discussions on the importance of narrative as a means to effectively communicate the causes and consequences of climate change [9-12], or in the case of infectious disease, the value of narrative in encouraging vaccine uptake $[13,14]$. Our focus here is largely on NCDs. There is little doubt that narrative and storytelling is employed by multi-national purveyors of unhealthy commodities, and the politicians who clear a path for their distribution. We argue that not only does the illness narrative of the patient in the waiting room need to be taken into consideration, it is also an imperative that patients understand how they are unduly influenced by the larger narratives that operate around them, narratives that influence mindsets, and ultimately biophysiology. Moving along the continuum, selective narratives can compromise (or conversely, provide hope, motivation, and vision toward) the aims of planetary health [15-17].

To illuminate our contentions, we use a story of our own; here, two individuals will each consume a McDonald's ${ }^{\circledR}$ Meal. The story will demonstrate that the biological buffering capacity in response to a fast-food meal does not sit on a level socioeconomic playing field.

\section{Narrative Medicine}

"In order to do simple medicine, one has to be able to understand complex narratives"

Rita Charon, MD, PhD, 1989 [18] 
The contemporary history of narrative medicine takes its shape in the early 1990s; during this time several physicians and medical school educators began publishing journal articles with titles, such as "Medicine as Storytelling" [19], "The Use of Narrative in the Doctor-Patient Encounter" [20], "Narrative and Medicine" [21], and "Medical Interpretation: Implications of Literary Theory of Narrative for Clinical Work" [22]. Coincident with these technical articles was a surge in popularity of lay press books written by physicians-exemplified by neurologist Oliver Sacks and others-in which the stories of patients are artfully retold by the healer.

This period also marked a massive rise in the popularity of alternative systems of healing; many scholars interpreted this as a surrogate marker for some of the deficits in the biomedicine-dominated practice of Western medicine [23]. The study of alternative systems of medicine is, by-and-large, the realm of placebo studies [24]. We will turn our attention to placebo and its connection to storytelling in more detail later. For now, we simply point out that among the primary reasons for visiting alternative providers, patients cite 'time with the provider' and 'feeling listened to' [25].

In medicine, time spent with patients was shrinking, and even within the confines of shorter visits, patients were provided $18 \mathrm{~s}$ to provide their narrative before being interrupted [26] (this continues to be an issue of major concern [27]). Aspects of the patient story are often dismissed as 'anecdote', and thus of lesser value in a medical culture that minimized the psychosocial in the biopsychosocial paradigm. Although the successes of biomedicine and the importance of competency in the scientific-technological aspects of medicine are undeniable, this very success might run the risk of obscuring the need to accumulate nontechnical skills-competencies that might further enhance beneficial outcomes for both the patient and physician [28,29].

In a landmark paper in the Journal of the American Medical Association (JAMA) (2001), narrative medicine was formally proffered by the physician, Dr. Rita Charon, as a model for empathy, reflection, professionalism, and trust. "Along with scientific ability, physicians need the ability to listen to the narratives of the patient, grasp and honor their meanings, and be moved to act on the patient's behalf. This is narrative competence, that is the competence that human beings use to absorb, interpret, and respond to stories", wrote Charon. Narrative medicine was described as a framework that provides all physicians with "skills, methods, and texts to learn how to imbue the facts and objects of health and illness with their consequences and meanings" [30].

Now cited over 1700 times on Google Scholar, there is little doubt that Charon's narrative medicine paper-published in one of the leading biomedicine journals-was the fountainhead of an inevitable movement. Central to the movement is the idea that narrative is both a source of knowledge-a rich pool of vital information provided by the patient-and, in the hands of the competent clinician, a medical 'device' to be employed [31]. Narrative competency involves immersion in the situation of the individual providing the story-their biological, psychological, social, economic, and cultural lived experience-while recognizing the meaning of the events as they are described.

The competent physician bears witness to the sufferer, which in turn increases the likelihood that the 'whole story', with its clinically-relevant pieces, will be revealed. In addition, narrative medicine argues that the skill of physician self-reflection-a central feature of competency-encourages greater empathy and resilience for both patient and healer. Finally, it has also been argued that narrative skills increase the likelihood that physicians will envision, and more effectively communicate, the stories of medical science. Thus, narrative competency has the potential to strengthen professionalism while increasing public trust.

The practical application of narrative medicine includes open-ended questions and first-visit opening questions, such as "What would you like me to know about you?", before engaging in specific queries on symptoms. It also includes uninterrupted listening and identification of key words or metaphors within the patient narrative. In the realm of self-reflection, the physician examines potential assumptions about the patient and at what point an assumption or stereotype (for example, on patient obesity) may have entered into the alliance. Asking the patient questions, such as "What do you think is going on?", can allow a story to unfold, facilitating attributions and exploration of patient fears [32]. 
In addition, the practical application of narrative medicine includes writing; creative and/or reflective writing on the part of the clinician. In particular, the development of a 'parallel chart' is encouraged, one distinct from the usual "SOAP" (subjective, objective, assessment, plan) patient chart. The parallel chart is a post-visit reflection that explores thoughts, feelings, and additional questions that were brought forth by the patient visit [33]. Charon describes the advantages of training in the practice this way: "When learners are asked to represent complex events or states of affairs in words, they confer form on otherwise formless situations. The very conferring of form-as a short story, a poem, an obituary, a love letter-makes visible an invisible situation, otherwise marooned in some chaotic memory ... with practice, we can improve this native ability to enter others' narrative worlds and to visualize others' perspectives on these worlds." [34].

In short, narrative medicine operates from the perspective that patients are more than the sum of their symptoms, and that careful attention to the personalized narratives can reveal clinically-relevant knowledge. This narrative knowledge will, in turn, beneficially influence diagnosis, treatment, and preventive care advice. On the provider end of the equation, research shows that narrative medicine is well received by healthcare providers and students (improving communication skills, personal growth, inter-professional bonds, and occupational satisfaction) [35-37], reduces emotional exhaustion [38], and increases enduring empathy [39,40]. On the patient outcomes side, the research remains thin and lacks specificity [41,42]; however, there is some evidence that narrative approaches lower polypharmacy, over-diagnosis, and the ordering of unnecessary tests [43] and improve objective markers of health [44].

Although narrative medicine can be an essential tool throughout clinical care, it is in the context of NCDs where it might offer its greatest potential. Unhealthy dietary choices, sedentary behavior, excess alcohol/substance abuse, and tobacco use are the primary factors in the annual burden of mortality and chronic disease [45-47]. NCD-related mortality statistics belie the preceding loss of individual and community vitality, and quality of life. In reality, the root lifestyle causes of NCDs are taking both years from life, and life from years [48]. Understanding the stories of patients (and, as we will discuss in detail shortly, the forces that interfere with the adoption of healthy lifestyles) can clear a path to meaningful change.

\section{Narrative Medicine, at Large}

"Planetary health—the health of human civilisations and the ecosystems on which they depend-has evolved into a capacious interdisciplinary inquiry. Yet it is neither capacious nor interdisciplinary enough. Planetary health, at least in its original conception, was not meant to be a recalibrated version of environmental health, as important as environmental health is to planetary health studies. Planetary health was intended as an inquiry into our total world. The unity of life and the forces that shape those lives" [49]

The quote above, from Lancet Editor-in-Chief Dr. Richard Horton, highlights that planetary health is more than specific units of analysis, single exposure indicators, and/or jargon related to quantitative toxin-based environmental impact assessments. Of course, those are important. However, in order for scientists to see the relevancy of each other's work (or even the relevancy of one's own work) in solving interconnected global challenges [50], and for physicians to take action as engaged educators in the context of planetary health [51], an efficient narrative is a necessity.

It is our contention that the skills of narrative competency, those at the heart of narrative medicine, can aid in the awareness of planetary health. As mentioned, in clinical settings, narrative competency involves immersion in the situation of the individual. At larger scales, narrative 'medicine' for the planet involves immersion in the interconnected, interdependent systems of life. If the health of the person in the waiting room is intimately connected to the sustainable vitality of all ecosystems, then how best to convey that message?

The competencies of narrative medicine are essential to 'narrative' and storytelling within science communication. Science (and thus scientific medicine) has a crisis of misinformation on 
its hands [52,53], made worse by the shifting cultural sands of what defines expertise and who, precisely, should be trusted as 'experts' [54]. Falsehoods spread through internet and social media channels, even more readily than truths; this may be due to the way such stories induce anxiety, disgust, and surprise [55]. Even a single piece of visual art (say, an image of a crying child accompanying a vaccine article [56]) can compromise public health goals. There is a strong likelihood that a patient in the waiting room (or community members at large) have been exposed to falsehoods-fear, shock, and disgust might be absorbed into their own subsequent health narratives.

At least one part of the pathway forward requires a better understanding of the way falsehood exposure and narrative is used to capture emotions, and ultimately beliefs [57]. Consider laboratory research that manipulates vaccine narratives as presented by a fictional parent or a doctor. The 'knowledge' is transmitted along linear chains of confederates; researchers find that experience-based views held by a parent (including the benefits of vaccines) is far better transmitted than the medical-based view held by the doctor. The narrative and the source influences vaccine uptake [58]; trying to counteract vaccine hesitancy (let alone unbridled anti-vaccine pseudoscience) with authoritarian narratives does not move the needle (literally and figuratively) [59,60].

The application of narrative in science communication (SciComm), while essential, requires caution. If narrative is employed in SciComm simply to persuade an 'ignorant' public—unknowing in the ways of science-that it needs protecting, it can appear as a public relations campaign in virtue-signaling. There are many cultural examples of such measures backfiring-it can send an elitist message that science does not trust the public [61].

It has also been pointed out that narrative messaging is in many ways an "unscientific" way of knowledge production; that is, it is distinct from the scientific reasoning used to search for truths [62]. Reliance upon narrative without a simultaneous reminding of the need for scientific reasoning can impair the quest for truths about the natural world, and elevate the anecdote. Thus, science-based stories might be best constructed in ways that celebrate both the humanism involved in tackling the interconnected grand challenges of our time, and the ways in which scientific reasoning has overcome obstacles.

However, in the context of the science of health and vitality, it is important to point out that science is not always virtuous. How did we get to Anthropecene Syndrome? Humans (and their funding 'appendages') decide upon the "obstacles" worthy of overcoming. Patients, communities, and policy makers should be fully aware that while one scientist is working on the obstacles of infectious disease (e.g., vaccine development), another is using scientific reasoning to overcome the "obstacle" of how to make already-ultra-processed foods even more palatable [63,64].

The story of Jonas Salk and the polio vaccine might provide the ideal example of relatable narrative and scientific reasoning. Salk arrived at an understanding of disease complexities by visualizing himself as a virus-“I tried to put myself in the place of the virus, and the immune system, and see how they would behave and why" [65]. However, Salk has another elegant 1955 story that conflicts with the neoliberal 'ownership' narrative that has since been absorbed by science and medicine.

He was asked who, or what, entity maintained patent ownership of the vaccine that would transform planetary health. "Well, the people I would say. There is no patent. Could you patent the sun?" responded Salk. Today, in an era of extraordinary medical costs and complex psychosocially-driven NCDs, medical science narratives need to be truthful about the fact that science is a human endeavor. Who decides what truths are worthy of pursuit? Does the race to intellectual 'property' act as an impediment to health equity and planetary health? [8]. The person in the waiting room-unduly influenced by fake news-needs to be (re)assured.

\section{Beliefs, Narrative, Mindsets}

"Narrative art, by virtue of its form, matches the belief structure implied by an ongoing life. The beliefs ... that can be inferred from a particular narrative may either reinforce or challenge the beliefs of its readers or hearers, but the potential for significant engagement between the beliefs of the narrative 
determined by its form and the belief structure of the reader is crucial to the relation of narrative to human life"

Wesley A. Kort, PhD, 1985 [66]

Central to stories of health at all scales is the word, belief(s)—the messy material upon which narrative is built and interpreted. The patient and the healer bring unique sets of beliefs, expectations, and agency (motivations to work toward specific goals) to the intimate encounter. By default, this necessitates discussions of 'mindsets' and/or the broad term 'placebo effect' (Figure 2). The placebo effect has been thoughtfully defined as "a bodily change due to the symbolic effects of a treatment or treatment situation and not due to its pharmacologic or physiologic properties" [67]).

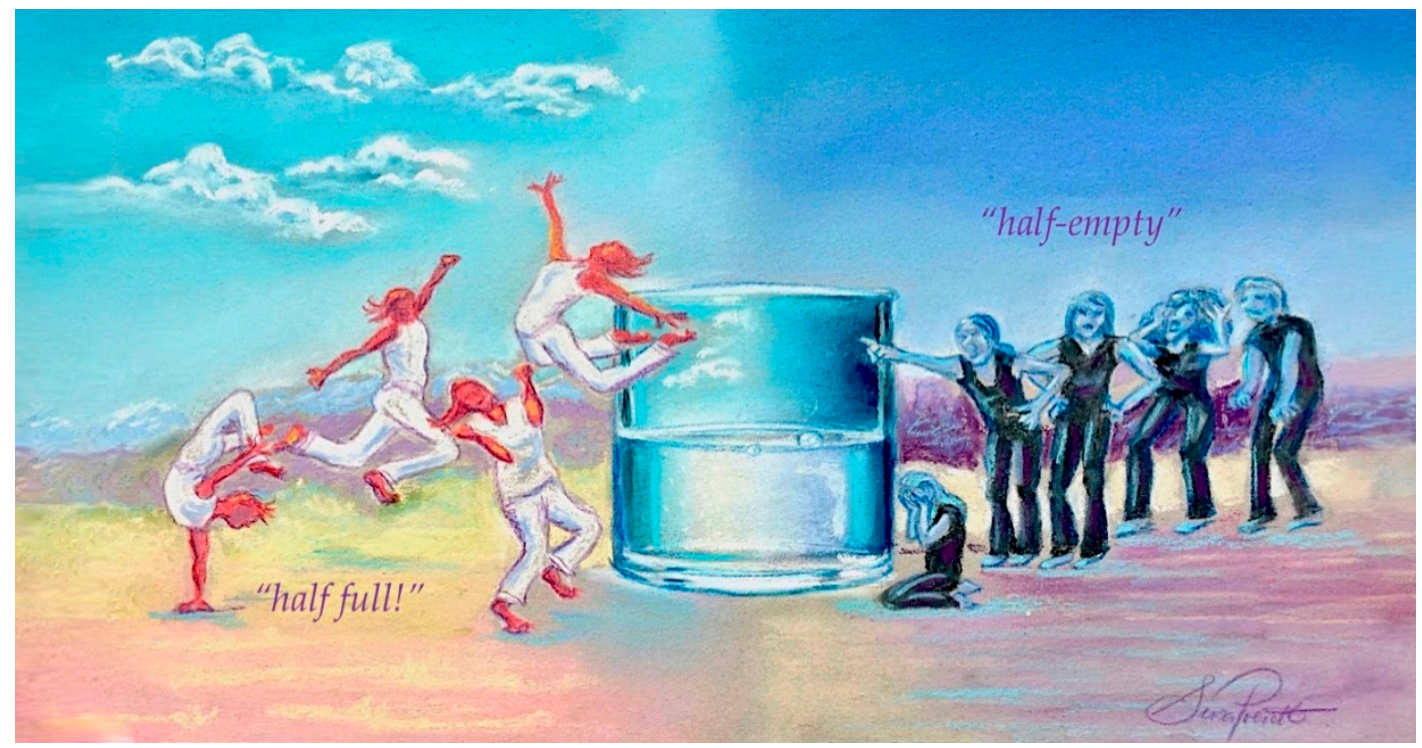

Figure 2. Narratives that prime attitudes and expectations have tangible health effects (on stress, inflammation, and aging). Decades of research showing subjective, physiological, and functional effects of placebo.

Note that what constitutes a "placebo" should not be confined or restricted since there are wide-ranging treatment situations capable of provoking symbolic effects. In other words, a placebo cannot be narrowed to "inert" pills, injections, and the like. The psychological and biological effects are what matter. The extent to which the symbols of healing can induce bodily change-let us say lower pain or improve depressive symptoms-are based on the beliefs and expectations held by patients [68-70]. Nocebo effects are also highly relevant. For example, beliefs concerning the dangers and side-effects of drugs can manifest as bodily changes also, but not in the desired direction [71,72].

In 1910, Flexner referred to patients drawn to traditional systems of healing and responsive to its placebo effects as medical dissenters: "certain profound characteristics in one way or another support the medical dissenter; now, the primitive belief in magic crops up in his credulous respect for an impotent drug" [73]. The Flexner teaching model—aided by subsequent advances in laboratory-based biomedicine-sidelined placebo to the stuff of superstitions. However, in 1977, the famed placebo researcher, Henry Beecher, said "Today's medicine, which many find irrelevant to the patients' needs, is the fruit of Flexner's report"-Beecher also preferred to think of medicine "as a branch of sociology" [74]. It has been no coincidence that the rise of narrative medicine has occurred in parallel with placebo studies; both are a product of Western medicine's slow crawl (back) to the realization that psychosocial factors play an enormous role in health-causes, consequences, prevention, and treatment.

The narratives provided on product labels-symbolism found in text, branding, and imagery-influence health-related psychobiological outcomes [75,76]. Extensive studies using objective physiological markers now demonstrate that levels of expectancy concerning 
treatments-even if those treatments are drops of water or sugar pellets-produce biological changes $[77,78]$.

The biological consequences of expectancy derived through storytelling could have significant benefits when viewed through the lens of sociobiological evolution [79]. Consider the famous "Ice Man" (who lived 5300 years ago) - analysis shows that he, like many of our ancient ancestors, used medicinal herbs, including those that are the basis of contemporary antimicrobials, analgesics, and laxatives [80]. Today, the strict limits of evidence-based medicine would consider these "useless". However, beyond the direct physiological effects (whatever they might be), the expectations concerning medicinal, plant-derived agents surely had survival value to the Ice Man and his kin.

The emerging research on open-label placebos illustrates the power of beliefs and 'the story'. Even when subjects are explicitly informed that an agent or suggestion is 'inert' - in that it has no direct biological relevance to illness-beneficial health-related outcomes are still realized [81-88]; these studies are challenging the Flexner-inspired narratives. Not only are medical journal editorials encouraging clinicians to stay well versed in the realm of placebo studies [89], some state that it is clearly ethical to foster the placebo effects, and are asking medicine-at-large whether or not it is ethical to allow "the patient suffer in the name of truth or to expose him or her to nocebo effects" [90].

A greater understanding of expectancy-how beliefs are formed and how they might change during treatments-has the potential to transform clinical practice [91-94]; for now, the first Expert Consensus on the Implications of Placebo and Nocebo Effects for Clinical Practice (2018) [95] concludes with five action points:

1. Consider placebo effects as part of regular treatment;

2. Inform patients about placebo and nocebo effects in such a way that treatment effects are maximized and side effects are minimized;

3. Ensure a patient-clinician relationship that is characterized by trust, warmth, and empathy to maximize placebo effects and minimize nocebo effects;

4. Train health-care providers in patient-clinician communication to maximize placebo effects and minimize nocebo effects; and

5. Prefer open-label rather than hidden placebo prescription in those cases where there is evidence for efficacy and where prescribing a placebo is legal [95].

The exciting advances in placebo studies-especially when intersecting with the parallel topic of narrative medicine-provide an opportunity for expansive discussions on community and planetary health. Engaging narratives-just like the symbols of healing-are well capable of influencing bodily systems, including cardiac and electrodermal activity, oxytocin release, and objective brain measurements [96-98]. With greater knowledge of the components of stories that are most likely to provoke physiological responses, there is hope that narratives of planetary health-even those that might challenge existing belief systems - can be constructed in ways that lead to meaningful action.

Importantly, the 'benefits' of the placebo (through clinician warmth, empathy, patient engagement, and support) may not be distributed equally in society. Rather they may be yet one more component of health disparities [99]. For example, research indicates that patients in disadvantaged areas perceive the empathy of their physicians to be much lower than that afforded to physicians in affluent areas [100,101], and perceptions of physician empathy are associated with good medical outcomes [102,103]. Moreover, alternative systems of healing, steeped in placebo therapeutics, are often directed at (and consumed by) socioeconomically privileged groups [104,105].

In sum, there are many ways in which the study of mindsets - and the lessons already learned from placebo studies-can be applied on a larger scale. In the clinic, it is clear that expectancies are influenced by the cultural mindsets and contexts large and small $[106,107]$. It seems obvious that the factors which foster positive expectancies-empathy, competence, trust, warmth, assurance, respectful discourse-are of relevance at community and global levels. In the planetary health context, the Earth 
can play the role of both the patient and provider-hence, a universal narrative for a healthy planet is an imperative [108-110].

\section{Narrative, Neoliberalism, NCDs-Beyond Narrow Clinical Confines}

"Narrative medicine was born from the crises engendered by the new market commandism-that is, the neoliberal fix - that economic and political elites across the Global North adopted in the wake of mass protracted struggles for economic redress and social inclusion that the 1960s and 1970s ushered in, and that still resound to this day".

Edgar Rivera Colon, PhD. In, Principles and Practice of Narrative Medicine, 2017 [111]

Part of the maturation of a discipline or concentrated subject matter is the application of critical discourse; the quote above from Dr Colon dares to examine the roots of narrative medicine. It exemplifies material excluded from discussions of narrative medicine as they took shape in the leading Western biomedicine journals. Certainly nothing of this flavor appeared in JAMA [30], the Annals of Internal Medicine [112], or the New England Journal of Medicine [113] when narrative medicine was introduced.

Perhaps out of necessity (in order to gain access to leading biomedical journals), it tells a comfortable tale of physicians being powerful beings-in the words of the author, "anointed as agents of social control who deploy special powers to rescue, heal, and take command". The JAMA paper elides even superficial discussions of social dominance orientation, authoritarianism, elitism, power, and neoliberalism within Western medicine [114-116], or the ways in which it has contributed to disparities [117]. It leaves out the storied reasons—some elegantly outlined by Dr Colon—that narrative medicine became a necessity in the first place.

At inception, narrative medicine overlooked the fact that Western biomedicine and its institutionalized delivery has a narrative of its own; as others have pointed out regarding specialized, non-technical 'competencies' - like cultural competency-the power dynamic of Western medicine is often assumed to be normative and just [118]. Medical students are asked to learn about 'others' (often the minority) and self-reflect from the 'we in medicine' perspective; missing is the mandate to reflect upon the cultural 'us' (that is, the culture of Western medicine of which the physician is a team member) and the privileged structure from which the absorption of narrative takes place $[119,120]$.

Some $70 \%-90 \%$ of NCDs are attributable to environmental differences over time-genetic determinants are relatively small [121]. In the United States, provider-driven clinical care is estimated to account for only $16 \%$ of the modifiable determinants of healthy outcomes within the population; the bulk of health determinants among Western populations are found in socioeconomic factors and health behaviors [122]. As mentioned earlier, lifestyle and environmental exposures are the drivers of NCD-related early mortality.

It is difficult to discuss NCDs or narrative medicine at any depth without considering the neoliberal ideology that pushes short-term economic interests and drives materialism around the globe. Neoliberalism emphasizes possessive individualism, acquisition, competition, and 'ownership' into social, cultural, political, and scientific arenas. Its policies and practices are maintained through dynamics of power associated with affluence, militarism, and coercive relations [123-125]. Neoliberalism proffers that the sole responsibility for health and healthy behaviors sits with the individual.

In the name of personal "freedom" - since the individual is the primary holder of preventive strategies for one's own health-neoliberalism offers products and services for individuals with mental distress, obesity, type II diabetes, and other NCDs. Solutions to 'undo' the consequences of the heavily marketed drivers of NCDs-the sort that everyone except the 'undisciplined' enjoy in moderation and as "part of a balanced diet" — take the form of highly-marked-up healthcare, medical technology, medical devices, patent-protected pharmaceuticals (especially psychotropic medications), dietary supplements, etc. [8]. 
Teams of international marketing scientists are hard at work peeling back the structural layers of a 'brand story' in order to maximize persuasion, to 'arouse consumer brand fantasy' [126], and to develop stories that inspire consumers on their quest to a 'hedonic multisensory experience' [127]. Put simply, neoliberalism is fascinated by the key components of persuasive narrative. While unabashedly exhausting the Earth's resources, neoliberalism continues to provide immense consumer choices, including the ultra-processed foods, sweetened beverages, alcohol, tobacco, etc., that contribute to NCDs [128].

Neoliberalism obviously privileges the 'bio' within the biopsychosocial paradigm. However, its narratives also obfuscate the biological consequences of the otherwise meaningful connections between the social and the psychological [129]. For example, neoliberalism 'tells' individuals that if they are in debt, it is their fault. Absorbing this view into the psyche-that is, that personal debt is a failure-is associated with higher blood pressure and adiposity [130]. We will examine this in more detail when we take up the case of the McDonald's ${ }^{\circledR}$ Meal below.

Undoubtedly, personal responsibility is important in human health; but NCDs do not appear at random in Westernized nations (Figure 3). They cluster such that the burden is shouldered by the socioeconomically disadvantaged. Narratives behind the non-random incidence of NCDs can describe an unwillingness to upend the status quo that otherwise maintains grotesque health inequalities and ignores how policies influence the lifestyle aspects of health - the causes of the causes [131,132]. Disadvantaged individuals and communities are provided with the same advice as the affluent-eat healthy, exercise, refrain from tobacco use, and avoid excess alcohol—but the lifestyle playing field is not level.

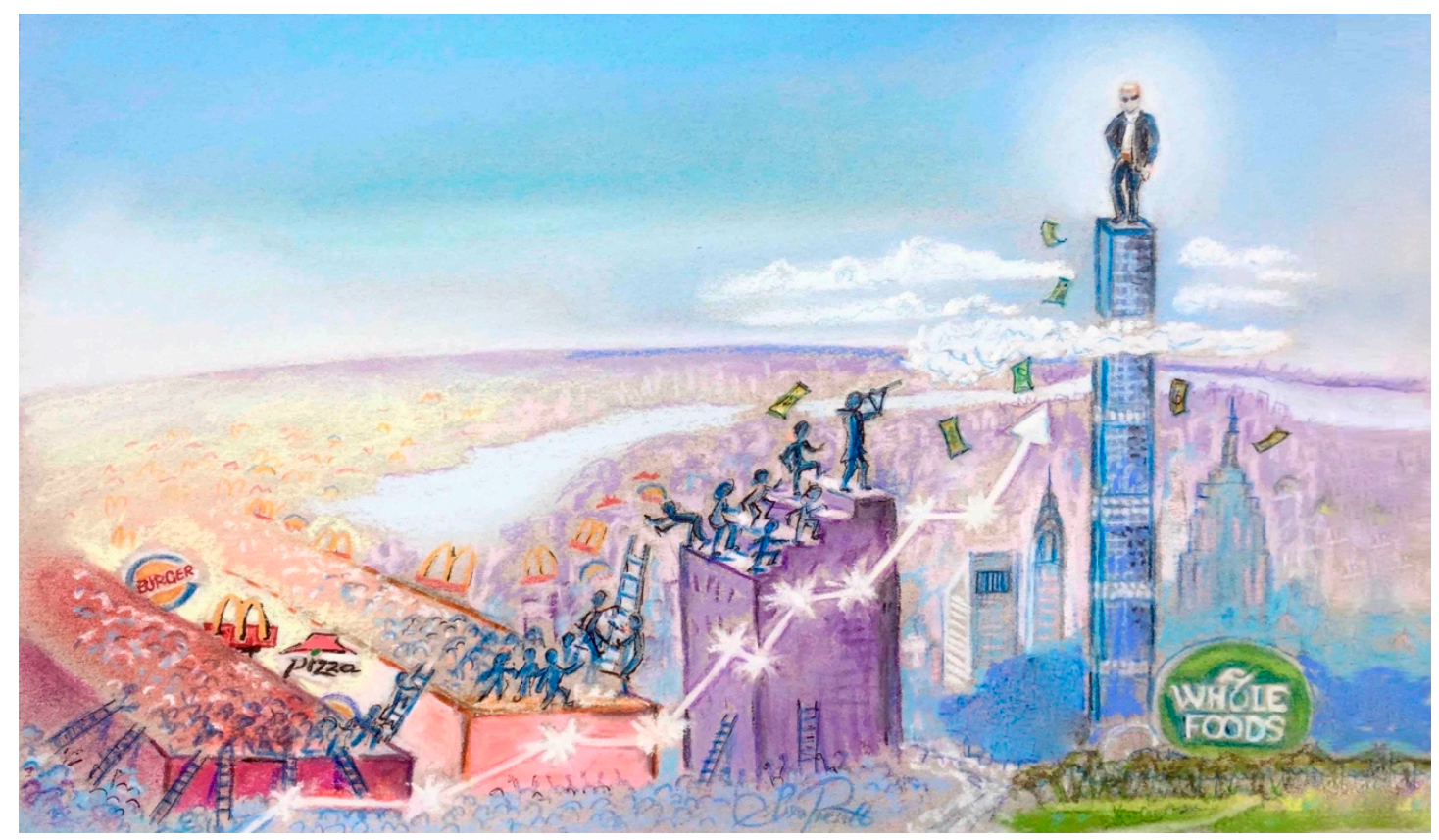

Figure 3. Neoliberal ideologies dominate social, cultural, political, and scientific narratives: Promote possessive individualism, acquisition, competition, and ownership, which perpetuate extreme socioeconomic gradients and vast health inequalities.

In the leafy, affluent neighborhood, access to healthcare is more assured, as is greater access to healthy foods within well-stocked supermarkets. In addition, there are more likely to be safe, well-maintained parks and vegetation-rich areas of green space. However, as we shall discuss below, the affluent neighborhood is also defined by absences-it is not just greener, it is less grey.

Green space has its opposite pole, something we have previously defined as 'grey space' [133,134]; these are areas not only deficient in quality parks and vegetation-dense areas for recreation. Grey space 
is also characterized by the presence of the unhealthy commercial determinants of health - greater industrial activity, higher concentrations of fast food outlets, convenience stores, bars, liquor stores, and tobacco vendors. For example, in the United Kingdom there are five times as many fast-food outlets in disadvantaged areas vs. affluent communities [135]. Moreover, they cluster with alcohol, tobacco, and gambling outlets [136].

However, grey space is also marked by more than easily-identifiable physical structures and chemical toxins, such as airborne particulate matter and soil contaminants-it is the presence of profit-driven marketing (and targeted marketing specifically to the disadvantaged), the narratives found on billboards, sidewalk signage, the in-store magnification of unhealthy products, ultra-processed foods cleverly placed on the 'end-caps' of the aisle (e.g., sales of sugar-rich beverages, biscuits, or chips increase by $300 \%-400 \%$ when placed at the coveted end-of-aisle position [137]). It is a place where you are likely to find discounted tobacco for sale, even in pharmacies [138].

Grey space is thus an engineered environment that serves to insidiously reinforce unhealthy behavior. It compromises a positive psychological outlook and, ultimately, trans-generational health. Mixed into the story of the person in the waiting room are other characters. The 'health' alliances between multi-national purveyors of unhealthy goods-ultra-processed foods, tobacco, alcohol—and highly-trusted medical, public health, and government institutions are part of the 'plot' line [139]. The narrative is that these companies are there to help. They are concerned about that consumer with type-II diabetes in the waiting room-and they have got their back. Thus, there is no need to regulate, alter policy, or tinker with vending machines [140-144].

This is a global narrative-it gets under the skin and into the alimentary canal; forensic analysis can identify neoliberal fingerprints and "DNA" in the microbiome of the intestinal villus and 'in the periphery', circulating as a measurable metabolome of the patient in the waiting room [145]. As pointed out by experts in public health, multi-national corporations and other commercial enterprises can maintain grey space and grotesque health inequalities by 'controlling the narrative' [146]. Often they do this with the aid of front groups and quasi-scientific organizations operating behind the façade of trust and 'science' [147].

\section{The McDonald's ${ }^{\circledR}$ Meal Story}

"I expect money like you walk into a room and turn on a light switch or a faucet, it is not enough"

Ray Kroc, McDonald's Founder, 1973 (commenting on his massive fortune) [148]

To appreciate how external ecosystems-political, commercial, and otherwise-interface with internal ecosystems to differentially influence physiology, we can consider the story of a single McDonald's ${ }^{\circledR}$ Meal. In our story, two individuals will each consume a McDonald's ${ }^{\circledR}$ Meal. One consumer is socioeconomically disadvantaged, residing in South Los Angeles, and the other is from affluent, leafy green Bel Air.

We note at the outset that South Los Angeles makes up only $6.4 \%$ of the 500 square mile City of Los Angeles area, yet it houses about $45 \%$ of all fast-food outlets [149]; research also suggests that the neighborhood food environment is a strong determinant of overall dietary patterns [150]. However, the dominant neoliberal "think tank" narrative is that fast-food is "part of a balanced diet" and the rich enter the top fast-food chains as often as the disadvantaged. Thus, goes the narrative (based on research that does not quantify the specific foods actually consumed by the rich/poor in fast-food establishments [151]), fast-food cannot explain health disparities and the disadvantaged need no special zoning protection, at least not from a nutritional perspective.

Shortly after entering the gastrointestinal tract of healthy individuals-regardless of socioeconomic position— the McDonald's ${ }^{\circledR}$ Meal can promote oxidative stress, increase the expression of inflammatory genes, and disturb endothelial function [152,153]. Increased oxidative stress and low-grade inflammation is a consistent response to other fast and ultra-processed foods, placing a burden on the cardiovascular and other bodily systems [154-157]. The human body is capable of 
buffering against the detrimental effects of the single fast food meal; that is where the story ends for the neoliberal "think tank" and the unhealthy-product-industry front group. However, just as the total lived environment of leafy Bel Air differs from lower income South Los Angeles, the human biological buffering capacity does not sit on a level playing field [158].

Biologically, the response to the McDonald's ${ }^{\circledR}$ Meal interfaces with the background diet of the individual. The available research is robust. It 'tells' us that the disadvantaged consumer will likely have lower tissue levels of buffering dietary antioxidants and higher baseline levels of oxidative stress [159-165].

The extent to which a single, fast-food-style meal burdens the circulatory system, and elevates inflammatory immune chemicals, triglycerides, and insulin, is also intertwined with background physical activity, body mass index, baseline inflammatory state, and of course, psychological stress [166-168].

There is little doubt that higher levels of chronic, low-grade stress are experienced in South Los Angeles' disadvantaged neighborhoods compared to green (rich in both vegetation and money), billboard-free neighborhoods, like Bel Air; the emerging research indicates that neighborhood-level deprivation-low socioeconomic position and the entire package of grey space-is manifesting as inflammation, oxidative stress, disturbances to the gut microbiome (dysbiosis), alterations in the brain reward system, and metabolic dysregulation [169-174]. Research shows that baseline psychological stress compounds the inflammatory and detrimental circulatory responses to a single fast-food-style meal $[175,176]$.

The McDonald's ${ }^{\circledR}$ Meal narrative continues. The individual from South Los Angeles likely knows, precisely, what it feels like to live with deprivation. We can glean the implications of those feelings from experimental research, and how they might influence choices in a visit to a fast-food outlet. When researchers induce the mere 'feeling' of low socioeconomic position (that is, among research subjects who are not impoverished), the result is greater automatic preferences for fast-food and higher overall caloric intake [177]. Subjective feelings of poverty, powerlessness, and deprivation increase calories consumed during ad-libitum meals-with a stronger desire to consume foods [178-181]. This raises key questions about the environmental status signals, especially in childhood when eating behaviors are established (Figure 4).

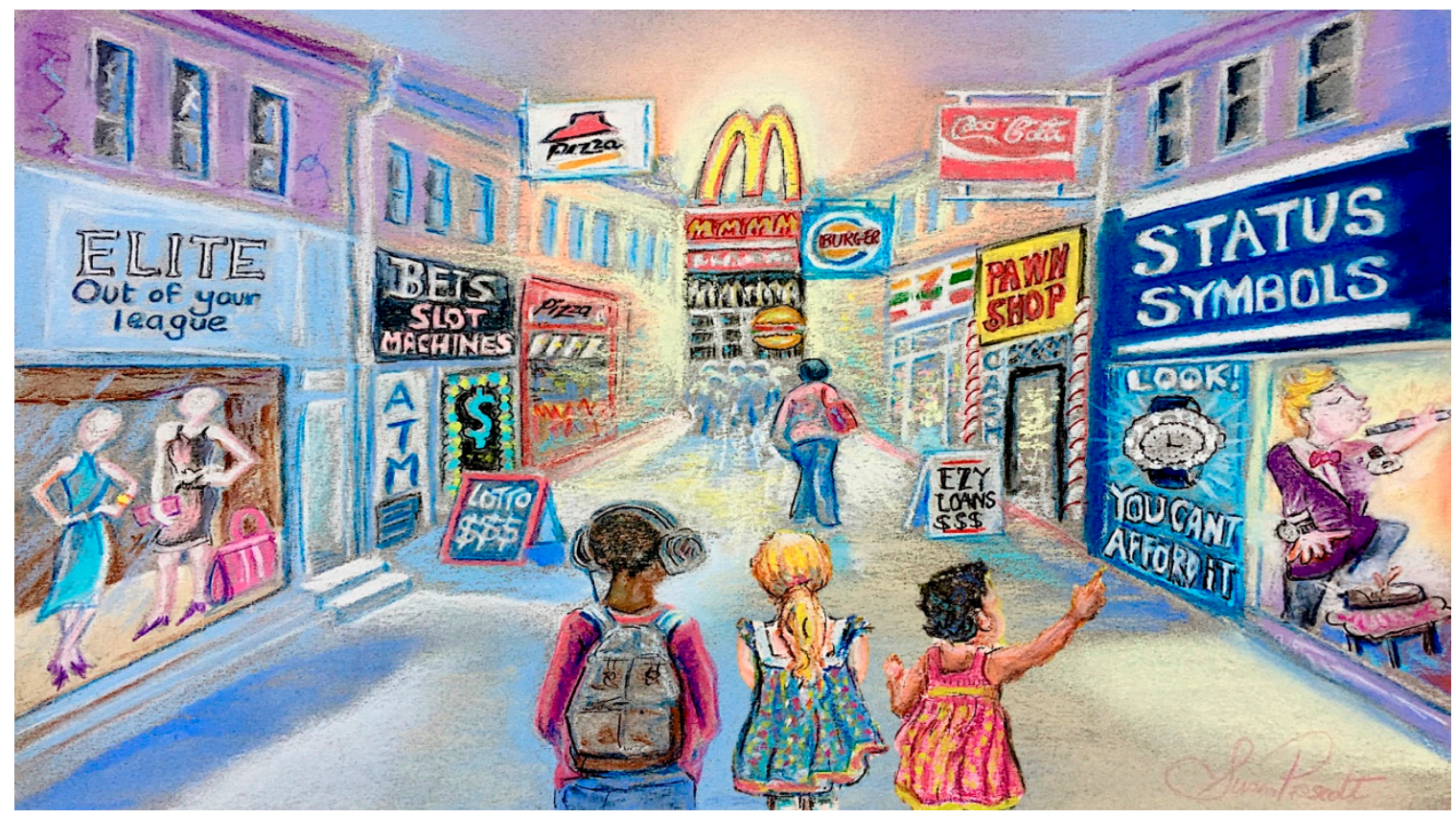

Figure 4. Environmental cues that promote 'feelings' of social inferiority and powerlessness increase preferences for fast-food and higher overall caloric intake [156-160]. 
Biologically, the mere induced feeling of low Socioeconomic position (SEP) penetrates the neuroendocrine system, increasing the hormone, ghrelin [182]. Although best known as the appetite-stimulating compound, ghrelin is much more; it is a marker of chronic stress [183]. Elevated levels are associated with increased reward-seeking behaviors and risk taking [184].

The affluent consumer can easily retreat from experimentally-induced 'mere feelings' of low SEP. In our narrative, the Bel Air resident drives back to the homelands where fast-food outlets are zoned out, and where, the SEP research tells us, the background diet will differ. It will likely be higher in daily intake of healthy plant foods and a lower intake of ultra-processed foods [185-187]; thus, these foods will circumscribe the McDonald's ${ }^{\circledR}$ Meal later in the day and/or the next morning. The fridge is likely to be full of goji berries, acai pulp, and what not.

The biological stories of minority and disadvantaged patients are also found in studies of discrimination; research shows that feelings of discrimination are associated with higher baseline low-grade inflammation [188-190]. When subjected to experimental stress, individuals with higher levels of perceived discrimination also have a magnified inflammatory response [191].

Research also tells us that the psychological asset of optimism is more abundant in privileged areas, like Bel Air; defined as possessing positive outcome expectancy for future events across life domains, it has been consistently linked to higher socioeconomic position [192,193]. It has also been associated with lower all-cause mortality [194], chronic disease [195], and lower body mass index [196]. Optimism is a mediator between job stress and resiliency against depression [197]. Biologically, baseline optimism predicts lower rises in blood pressure in response to oral narratives that induce anger or sadness [198] Optimism, the research tells us, predicts lower baseline inflammatory cytokine levels and C-reactive protein [196], and a lower inflammatory response to experimental stress [199].

The asset of optimism is also linked to yet another aspect of our McDonald's ${ }^{\circledR}$ Meal memoir; self-generated narratives describing positive events about the future (which is what optimists do) are associated with a greater willingness to postpone (delay) immediate rewards in favor of potentially larger benefits in the future $[200,201]$. On the other hand, a narrative that describes negative events - like major financial stress (which is what those with precariousness face)-leads to a desire for small immediate rewards and less concern about the future [202]. Discounting the potential value of future rewards, and instead prioritizing smaller immediate rewards, is associated with socioeconomic disadvantage [203-205]. Why does this matter to our semi-fictional fast-food consumers? Because higher concern for future consequences is a buffering asset associated with preventive care and healthy behaviors [206].

However, there is another reason why delay discounting matters in our scenario. The clustering of fast food outlets-the actual physical structures and what they represent-may increase delay discounting (again, meaning diminished concern for future consequences). Research shows that discounting the value of a future financial reward and opting for smaller immediate gains is more likely while answering questions in the vicinity of a fast-food outlet (vs. other food establishments). Moreover, in neighborhoods with higher concentrations of fast food outlets, respondents are also more likely to opt for smaller immediate rewards, wave off larger future gains, and have diminished levels of savoring (i.e., the ability to take notice of positive experiences, an asset linked to mental well-being) $[207,208]$. On the other hand, images of (or actually being in) green space-think Bel Air-have been shown to curb delay discounting [209-211].

Today, there is little doubt that a living wage is central to health equity [212-214]; for example, emerging research shows that in socioeconomically disadvantaged workers, relatively small wage increases are associated with subsequent reductions in depression and other NCDs [215,216]. Lack of a living wage or stagnant minimum wages in concert with a lack of welfare buffers can magnify stress and compound an unhealthy lifestyle (e.g., dietary choices) [217-220].

The odds that our Bel Air resident is working in a fast-food outlet are infinitesimally small. Not so for the South Los Angeles resident. Research tells us that socioeconomically disadvantaged individuals are more likely to live within clusters of fast-food outlets, and work within them [221]. Meantime, 
a gentle, soothing breeze blows in Bel Air; it is isolated from traffic noise and a concentration of fast-foods outlets. The story of global socioeconomic disparities tells us that they continue to climb; the life expectancy of the wealthiest US residents can exceed low-income individuals by 10-15 years [222].

\section{Redefining the Narrative}

"With deep attention, aided by the envisioning powers of representation, the therapeutic goal of healthcare is within sight-affiliation with the patient as partner, advocate, one who accompanies and witnesses the suffering of the other. Whether meeting for the first or hundredth time, patient and clinician have a shot at joining in mutual recognition, coming to see and accept and support one another"

Rita Charon, MD, PhD [223]

Expanding the affiliation, advocacy, and partnership principles of narrative medicine into a global idea-one that promotes the ideals of personal, public, and planetary health-could transform the quality of life in the Anthropocene. The journey toward this realization will require greater exposure to public health, social, and political sciences within medical education. More than ever before, medicine, science, and health (at all scales) are political discussions [5,224-227]. However, in comparison to other professions and even the general population, US physicians show low levels of civic participation $[228,229]$.

When physicians better understand the methods and sources used by commercial entities to undermine health - the ways in which operatives frame NCDs as, exclusively, issues of personal responsibility, and sow seeds of doubt in areas where there is scientific consensus-they will be better equipped to attend to the person in the waiting room $[64,140,146]$. The physician will more likely comprehend how the patient's narratives bump up against prevailing commercial—political—social narratives; the latter narratives otherwise press down upon the patient and take a backhoe to the notion of a biologically (and psychologically) level playing field $[158,230]$.

In storytelling terms, patients with lifestyle-driven NCDs need to understand that they are being played by powerful players. Research shows that such recognition can increase agency. For example, when young people are informed that the engineered ultra-processed and fast-food environment is a matter of power, inequality, and food justice, they are motivated to change [231]. Reframing the narrative in such ways is far more effective than the delivery of rinse-and-repeat academic instruction on the importance of healthy dietary guidelines [232-234]. Moreover, discussions of issues, such as taxes on sweetened beverages, can underscore how these policies-in addition to their direct benefits [235] — are an effort to challenge the narratives of the unhealthy product industry [236].

Clinicians advocate physical activity, especially outdoors in nature, and adherence to a Mediterranean-style diet. However, adherence to the latter-with all of its stress and inflammation-buffering components-is determined by income $[237,238]$. Increasing numbers of Americans are holding down two jobs-reflecting the inability of one job to provide a living wage [239]; the lack of a living wage, often referred to as 'in-work poverty', is an obvious barrier to adherence of the former, spending time outdoors in nature, and the realization of the oft-discussed 'work-life balance' [240,241].

Indeed, it is the personal stories of what it is like to exist without a living wage-their 'audacity' in demanding a doubling of US federal minimum wages-that produces meaningful change. The stories of individuals and communities living below a living wage can be found in Frank McCourt's Angela's Ashes, but there is also a horn o' plenty within journals sitting at the periphery of 'medicine' [242-245]. The jargonistic term, semi-structured interview, belies the profound stories collated under its technique-narratives of distress in the ecological theatre $[246,247]$. In the context of large-scale narrative medicine and 'evidence', it is important to ask whether or not research that drives decision-making is actually serving the person in the waiting room, or in the larger community [248]. 


\section{Conclusions}

"Language is a guide to 'social reality'. Human beings do not live in the objective world alone, but are very much at the mercy of the particular language which has become the medium of expression for their society. The worlds in which different societies live are distinct worlds, not merely the same worlds with different labels attached"

Edward Sapir, PhD, 1929 [249]

"The background linguistic system-in other words, the grammar - of each language is not merely a reproducing instrument for voicing ideas but rather is itself the shaper of ideas, the program and guide for the individual's mental activity, for analysis of impressions, for synthesis of mental stock in trade"

Benjamin L. Whorf, Research Fellow, Yale University, 1940 [250]

Storytelling is a central feature of the development and propagation of culture. Select words used within the story can be loaded with power, and cultural meaning; in Westernized nations, the word, medicine, is certainly used 'for synthesis of mental stock in trade'. In the Anthropocene, where it is abundantly clear that human health is inseparable from the health of the planet, the power of narrative and storytelling is a critical consideration.

Narrative medicine is part of a contemporary movement that underscores the importance of the story in healthcare. Its basic premise is as old as the history of medicine-it is not novel. However, in its current form, it has been described more appropriately as a 'global idea' [251]. In our Viewpoint paper, we have opened discourse on the wider applications of narrative medicine vis à vis planetary health in the post-truth era.

The problem for personal, public, and planetary health is that the evolutionary survival value of storytelling can be co-opted by narcissistic, nefarious, neoliberal narrators concerned only with their own fitness [252,253]. 'SciComm' ignores that reality at its peril. An understanding of narrative and storytelling can help health professionals of all stripes listen, bear witness to, and understand what is ailing individuals, communities, and the planet at large. Technological solutions directed at interconnected global challenges offer hope, but absent a 21st century planetary health narrative, we may, as Pulitzer-Prize-winning scientist, Rene Dubos, said "end up with a jumble of technologies and counter-technologies that will eventually smother body and soul" [254].

Author Contributions: S.L.P. and A.C.L. contributed to the research, preparation and review of the manuscript.

Funding: This work received no external funding.

Conflicts of Interest: S.L.P. reports the following: Scientific Advisory Board and speaker's fees from Danone Nutricia, Schiphol, Netherlands and Nestlé Nutrition Institute, Lausanne, Switzerland; consultancy fees from Bayer Dietary Supplements Division, Whippany, NJ, USA; speakers fees from Health World Inc., Queensland, Australia; research grants from the National Health and Medical Research Council (NHMRC) of Australia. A.C.L. has received consultancy fees from Genuine Health, Toronto, Canada and speaker's fees from Health World Inc., Queensland, Australia. None of these relationships had any influence in the writing of this manuscript.

\section{References}

1. Mishler, E.G. The Discourse of Medicine; Ablex Publishing: Norwood, NJ, USA, 1984.

2. Brown, D.E. Human Universals; McGraw-Hill: New York, NY, USA, 1991.

3. Smith, D.; Schlaepfer, P.; Major, K.; Dyble, M.; Page, A.E.; Thompson, J.; Chaudhary, N.; Salali, G.D.; Mace, R.; Astete, L.; et al. Cooperation and the evolution of hunter-gatherer storytelling. Nat. Commun. 2017, 8, 1853. [CrossRef] [PubMed]

4. The challenge of the post-truth era. Nat. Cell Biol. 2018, 20, 1231. [CrossRef] [PubMed]

5. Iyengar, S.; Massey, D.S. Scientific communication in a post-truth society. Proc. Natl. Acad. Sci. USA 2018. [CrossRef] [PubMed]

6. Chou, W.S.; Oh, A.; Klein, W.M.P. Addressing Health-Related Misinformation on Social Media. JAMA 2018. [CrossRef] [PubMed] 
7. Prescott, S.L.; Logan, A.C.; Albrecht, G.; Campbell, D.E.; Crane, J.; Cunsolo, A.; Holloway, J.W.; Kozyrskyj, A.; Lowry, C.A.; Penders, J.; et al. The Canmore Declaration: Statement of Principles for Planetary Health. Challenges 2018, 9, 31. [CrossRef]

8. Prescott, S.L.; Logan, A.C. Down to Earth: Planetary Health and Biophilosophy in the Symbiocene Epoch. Challenges 2017, 8, 19. [CrossRef]

9. Chapman, D.A.; Lickel, D.; Markowitz, E.M. Reassessing emotion in climate change communication. Nat. Clim. Chang. 2017, 7, 850-852. [CrossRef]

10. Wang, S.; Corner, A.; Chapman, D.; Markowitz, E. Public engagement with climate imagery in a changing digital landscape. WIREs Clim. Chang. 2018, 9, e509. [CrossRef]

11. Stoknes, P.E. Rethinking climate communications and the "psychological climate paradox". Energy Res. Soc. Sci. 2014, 1, 161-170. [CrossRef]

12. Feldman, L.; Hart, P.S. Is There Any Hope? How Climate Change News Imagery and Text Influence Audience Emotions and Support for Climate Mitigation Policies. Risk Anal. 2017. [CrossRef]

13. Bianco, A.; Mascaro, V.; Zucco, R.; Pavia, M. Parent perspectives on childhood vaccination: How to deal with vaccine hesitancy and refusal? Vaccine 2019, 37, 984-990. [CrossRef] [PubMed]

14. Dubé, È.; Gagnon, D. Trust, Information Sources and the Impact on Decision-Making: The Example of Vaccination. In Confidence and Legitimacy in Health Information and Communication; Paganelli, C., Ed.; John Wiley and Sons: Hoboken, NJ, USA, 2019; pp. 43-55.

15. Jepson, P. Recoverable Earth: A twenty-first century environmental narrative. Ambio 2019, 48, 123-130. [CrossRef] [PubMed]

16. Robinson, J.M.; Mills, J.G.; Breed, M.F. Walking Ecosystems in Microbiome-Inspired Green Infrastructure: An Ecological Perspective on Enhancing Personal and Planetary Health. Challenges 2018, 9, 40. [CrossRef]

17. Prescott, S.L.; Logan, A.C. Larger than Life: Injecting Hope into the Planetary Health Paradigm. Challenges 2018, 9, 13. [CrossRef]

18. Charon, R. Doctor/Patient, Reader/Writer:Learning to find the text. Soundings 1989, 72, 137-152.

19. Borkan, J.M.; Miller, W.L.; Reis, S. Medicine as storytelling. Fam. Pract. 1992, 9, 127-129. [CrossRef] [PubMed]

20. Shapiro, J. The use of narrative in the doctor-patient encounter. Fam. Syst. Med. 1993, 11, 47-53. [CrossRef]

21. Sacks, O. Narrative and medicine. Mt. Sinai J. Med. 1993, 60, 127-131. [PubMed]

22. Charon, R. Medical Interpretation: Implications of Literary Theory of Narrative for Clinical Work. J. Narrat. Life Hist. 1993, 3, 79-97. [CrossRef]

23. Eisenberg, D.M.; Davis, R.B.; Ettner, S.L.; Appel, S.; Wilkey, S.; Van Rompay, M.; Kessler, R.C. Trends in alternative medicine use in the United States, 1990-1997: Results of a follow-up national survey. JAMA 1998, 280, 1569-1575. [CrossRef]

24. Antonelli, M.; Donelli, D. Reinterpreting homoeopathy in the light of placebo effects to manage patients who seek homoeopathic care: A systematic review. Health Soc. Care Community 2018. [CrossRef] [PubMed]

25. McCaffrey, A.M.; Pugh, G.F.; O'Connor, B.B. Understanding patient preference for integrative medical care: Results from patient focus groups. J. Gen. Intern. Med. 2007, 22, 1500-1505. [CrossRef] [PubMed]

26. Beckman, H.B.; Frankel, R.M. The effect of physician behavior on the collection of data. Ann. Intern. Med. 1984, 101, 692-696. [CrossRef] [PubMed]

27. Singh Ospina, N.; Phillips, K.A.; Rodriguez-Gutierrez, R.; Castaneda-Guarderas, A.; Gionfriddo, M.R.; Branda, M.E.; Montori, V.M. Eliciting the Patient's Agenda- Secondary Analysis of Recorded Clinical Encounters. J. Gen. Intern. Med. 2018. [CrossRef] [PubMed]

28. Herman, J. Anecdote and objectivity. J. Clin. Epidemiol. 1991, 44, 725-726. [CrossRef]

29. Charon, R.; Banks, J.T.; Connelly, J.E.; Hawkins, A.H.; Hunter, K.M.; Jones, A.H.; Montello, M.; Poirer, S. Literature and medicine: Contributions to clinical practice. Ann. Intern. Med. 1995, 122, 599-606. [CrossRef] [PubMed]

30. Charon, R. The patient-physician relationship. Narrative medicine: A model for empathy, reflection, profession, and trust. JAMA 2001, 286, 1897-1902. [CrossRef] [PubMed]

31. Morris, D.B. Narrative medicines: Challenge and resistance. Perm J. 2008, 12, 88-96. [CrossRef]

32. Peterkin, A. Practical strategies for practising narrative-based medicine. Can. Fam. Phys. 2012, 58, 63-64.

33. Zaharias, G. Learning narrative-based medicine skills: Narrative-based medicine 3. Can. Fam. Phys. 2018, 64, 352-356. 
34. Charon, R. Narrative medicine in the international education of physicians. Presse Med. 2013, 42, 3-5. [CrossRef] [PubMed]

35. Small, L.C.; Feldman, L.S.; Oldfield, B.J. Using Narrative medicine to build community across the health professions and foster self-care. J. Radiol. Nurs. 2017, 36, 224-227. [CrossRef]

36. Cappuccio, A.; Sanduzzi Zamparelli, A.; Verga, M.; Nardini, S.; Policreti, A.; Porpiglia, P.A.; Napolitano, S.; Marini, M.G. Narrative medicine educational project to improve the care of patients with chronic obstructive pulmonary disease. ERJ Open Res. 2018, 4. [CrossRef] [PubMed]

37. Wesley, T.; Hamer, D.; Karam, G. Implementing a Narrative Medicine Curriculum During the Internship Year: An Internal Medicine Residency Program Experience. Perm J. 2018, 22, 17-95.

38. Winkel, A.F.; Feldman, N.; Moss, H.; Jakalow, H.; Simon, J.; Blank, S. Narrative Medicine Workshops for Obstetrics and Gynecology Residents and Association With Burnout Measures. Obstet. Gynecol. 2016, 128 (Suppl. 1), 27S-33S. [CrossRef]

39. Chen, P.J.; Huang, C.D.; Yeh, S.J. Impact of a narrative medicine programme on healthcare providers' empathy scores over time. BMC Med. Educ. 2017, 17, 108. [CrossRef]

40. Yang, N.; Xiao, H.; Cao, Y.; Li, S.; Yan, H.; Wang, Y. Does narrative medicine education improve nursing students' empathic abilities and academic achievement? A randomised controlled trial. J. Int. Med. Res. 2018, 46, 3306-3317. [CrossRef]

41. Fioretti, C.; Mazzocco, K.; Riva, S.; Oliveri, S.; Masiero, M.; Pravettoni, G. Research studies on patients' illness experience using the Narrative Medicine approach: A systematic review. BMJ Open 2016, 6, e011220. [CrossRef]

42. Barber, S.; Moreno-Leguizamon, C.J. Can narrative medicine education contribute to the delivery of compassionate care? A review of the literature. Med. Humanit. 2017, 43, 199-203. [CrossRef]

43. Cenci, C. Narrative medicine and the personalisation of treatment for elderly patients. Eur. J. Intern. Med. 2016, 32, 22-25. [CrossRef]

44. Houston, T.K.; Allison, J.J.; Sussman, M.; Horn, W.; Holt, C.L.; Trobaugh, J.; Salas, M.; Pisu, M.; Cuffee, Y.L.; Larkin, D.; et al. Culturally appropriate storytelling to improve blood pressure: A randomized trial. Ann. Intern. Med. 2011, 154, 77-84. [CrossRef] [PubMed]

45. McGinnis, J.M.; Foege, W.H. Actual causes of death in the United States. JAMA 1993, 270, $2207-2212$. [CrossRef] [PubMed]

46. Mokdad, A.H.; Marks, J.S.; Stroup, D.F.; Gerberding, J.L. Actual causes of death in the United States, 2000. JAMA 2004, 291, 1238-1245. [CrossRef] [PubMed]

47. Collaborators, U.S.B.o.D.; Mokdad, A.H.; Ballestros, K.; Echko, M.; Glenn, S.; Olsen, H.E.; Mullany, E.; Lee, A.; Khan, A.R.; Ahmadi, A.; et al. The State of US Health, 1990-2016: Burden of Diseases, Injuries, and Risk Factors Among US States. JAMA 2018, 319, 1444-1472. [CrossRef] [PubMed]

48. Katz, D.L. How to Improve Clinical Practice and Medical Education About Nutrition. AMA J. Ethics 2018, 20, E994-E1000. [PubMed]

49. Horton, R. Offline: Planetary health-worth everything. Lancet 2018, 391, 2307. [CrossRef]

50. Dubos, R. Science and man's nature. J. Am. Acad. Art. Sci. 1965, 94, 223-244.

51. Capon, A.G.; Talley Ac, N.J.; Horton, R.C. Planetary health: What is it and what should doctors do? Med. J. Aust. 2018, 208, 296-297. [CrossRef]

52. Ioannidis, J.P.A.; Stuart, M.E.; Brownlee, S.; Strite, S.A. How to survive the medical misinformation mess. Eur. J. Clin. Investig. 2017, 47, 795-802. [CrossRef]

53. Marmot, M. Post-truth and science. Lancet 2017, 389, 497-498. [CrossRef]

54. Eyal, G. For a sociology of expertise: The social origins of the autism epidemic. Am. J. Sociol. 2013, 118, 863-907. [CrossRef]

55. Vosoughi, S.; Roy, D.; Aral, S. The spread of true and false news online. Science 2018, 359, $1146-1151$. [CrossRef]

56. Wu, A.G.; Shah, A.S.; Haelle, T.S.; Lunos, S.A.; Pitt, M.B. Choosing the perfect shot-The loaded narrative of imagery in online news coverage of vaccines. PLoS ONE 2018, 13, e0199870. [CrossRef] [PubMed]

57. Pennycook, G.; Cannon, T.D.; Rand, D.G. Prior exposure increases perceived accuracy of fake news. J. Exp. Psychol. Gen. 2018, 147, 1865-1880. [CrossRef] [PubMed]

58. Jimenez, A.V.; Stubbersfield, J.M.; Tehrani, J.J. An experimental investigation into the transmission of antivax attitudes using a fictional health controversy. Soc. Sci. Med. 2018, 215, 23-27. [CrossRef] [PubMed] 
59. Greenberg, J.; Dube, E.; Driedger, M. Vaccine Hesitancy: In Search of the Risk Communication Comfort Zone. PLoS Curr. 2017, 9. [CrossRef]

60. Nyhan, B.; Reifler, J.; Richey, S.; Freed, G.L. Effective messages in vaccine promotion: A randomized trial. Pediatrics 2014, 133, e835-e842. [CrossRef] [PubMed]

61. Kirby, D.A. Harnessing the Persuasive Power of Narrative: Science, Storytelling, and Movie Censorship, 1930-1968. Sci. Context 2018, 31, 85-106. [CrossRef]

62. Dahlstrom, M.F.; Scheufele, D.A. (Escaping) the paradox of scientific storytelling. PLoS Biol. 2018, 16, e2006720. [CrossRef]

63. Ortiz, S.E.; Zimmerman, F.J.; Adler, G.J., Jr. Increasing public support for food-industry related, obesity prevention policies: The role of a taste-engineering frame and contextualized values. Soc. Sci. Med. 2016, 156, 142-153. [CrossRef]

64. Monteiro, C.A.; Cannon, G.; Moubarac, J.C.; Levy, R.B.; Louzada, M.L.C.; Jaime, P.C. Ultra-processing. An odd 'appraisal'. Public Health Nutr. 2018, 21, 497-501. [CrossRef] [PubMed]

65. Stoler, P. A conversation with Jonas Salk. Psychol. Today 1983, 5, 50-56.

66. Kort, W.A. Modern Fiction and Human Time: A Study in Narrative and Belief; University of South Florida Press: Tampa, FL, USA, 1985.

67. Brody, H. Meaning and an Overview of the Placebo Effect. Perspect. Biol. Med. 2018, 61, 353-360. [CrossRef] [PubMed]

68. Beasley, M.J.; Ferguson-Jones, E.A.; Macfarlane, G.J. Treatment expectations but not preference affect outcome in a trial of CBT and exercise for pain. Can. J. Pain 2017, 1, 161-170. [CrossRef] [PubMed]

69. Kalauokalani, D.; Cherkin, D.C.; Sherman, K.J.; Koepsell, T.D.; Deyo, R.A. Lessons from a trial of acupuncture and massage for low back pain: Patient expectations and treatment effects. Spine 2001, 26, 1418-1424. [CrossRef] [PubMed]

70. Rutherford, B.R.; Wall, M.M.; Brown, P.J.; Choo, T.H.; Wager, T.D.; Peterson, B.S.; Chung, S.; Kirsch, I.; Roose, S.P. Patient Expectancy as a Mediator of Placebo Effects in Antidepressant Clinical Trials. Am. J. Psychiatry 2017, 174, 135-142. [CrossRef] [PubMed]

71. Webster, R.K.; Weinman, J.; Rubin, G.J. Medicine-related beliefs predict attribution of symptoms to a sham medicine: A prospective study. Br. J. Health Psychol. 2018, 23, 436-454. [CrossRef]

72. Webster, R.K.; Weinman, J.; Rubin, G.J. A systematic review of factors that contribute to nocebo effects. Health Psychol. 2016, 35, 1334-1355. [CrossRef]

73. Flexner, A. Medical Education in the United States and Canada: A Report To the Carnegie Foundation For the Advancement of Teaching; The Carnegie Foundation for the Advancement of Teaching: New York, NY, USA, 1910.

74. Beecker, H.K.; Altschule, M.D. Medicine at Harvard; University Press of New England: Hanover, NH, USA, 1977.

75. El Brihi, J.; Horne, R.; Faasse, K. Prescribing Placebos: An Experimental Examination of the Role of Dose, Expectancies, and Adherence in Open-Label Placebo Effects. Ann. Behav. Med. 2018. [CrossRef]

76. Faasse, K.; Martin, L.R. The Power of Labeling in Nocebo Effects. Int. Rev. Neurobiol. 2018, 139, $379-406$.

77. Darragh, M.; Vanderboor, T.; Booth, R.J.; Sollers, J.J., 3rd; Consedine, N.S. Placebo 'serotonin' increases heart rate variability in recovery from psychosocial stress. Physiol. Behav. 2015, 145, 45-49. [CrossRef] [PubMed]

78. Belcher, A.M.; Ferre, S.; Martinez, P.E.; Colloca, L. Role of placebo effects in pain and neuropsychiatric disorders. Prog. Neuropsychopharmacol. Biol. Psychiatry 2018, 87, 298-306. [CrossRef] [PubMed]

79. Colloca, L. Placebo, nocebo, and learning mechanisms. Handb. Exp. Pharmacol. 2014, 225, 17-35. [PubMed]

80. Capasso, L. 5300 years ago, the Ice Man used natural laxatives and antibiotics. Lancet 1998, 352, 1864. [CrossRef]

81. Meeuwis, S.H.; van Middendorp, H.; Veldhuijzen, D.S.; van Laarhoven, A.I.M.; De Houwer, J.; Lavrijsen, A.P.M.; Evers, A.W.M. Placebo Effects of Open-label Verbal Suggestions on Itch. Acta Derm. Venereol. 2018, 98, 268-274. [CrossRef] [PubMed]

82. Kelley, J.M.; Kaptchuk, T.J.; Cusin, C.; Lipkin, S.; Fava, M. Open-label placebo for major depressive disorder: A pilot randomized controlled trial. Psychother. Psychosom. 2012, 81, 312-314. [CrossRef]

83. Sandler, A.D.; Bodfish, J.W. Open-label use of placebos in the treatment of ADHD: A pilot study. Child Care Health Dev. 2008, 34, 104-110. [CrossRef] [PubMed] 
84. Zhou, E.S.; Hall, K.T.; Michaud, A.L.; Blackmon, J.E.; Partridge, A.H.; Recklitis, C.J. Open-label placebo reduces fatigue in cancer survivors: A randomized trial. Support Care Cancer 2018. [CrossRef] [PubMed]

85. Kam-Hansen, S.; Jakubowski, M.; Kelley, J.M.; Kirsch, I.; Hoaglin, D.C.; Kaptchuk, T.J.; Burstein, R. Altered placebo and drug labeling changes the outcome of episodic migraine attacks. Sci. Transl. Med. 2014, 6, 218 ra5. [CrossRef]

86. Carvalho, C.; Caetano, J.M.; Cunha, L.; Rebouta, P.; Kaptchuk, T.J.; Kirsch, I. Open-label placebo treatment in chronic low back pain: A randomized controlled trial. Pain 2016, 157, 2766-2772. [CrossRef]

87. Hoenemeyer, T.W.; Kaptchuk, T.J.; Mehta, T.S.; Fontaine, K.R. Open-Label Placebo Treatment for Cancer-Related Fatigue: A Randomized-Controlled Clinical Trial. Sci. Rep. 2018, 8, 2784. [CrossRef] [PubMed]

88. Schaefer, M.; Harke, R.; Denke, C. Open-Label Placebos Improve Symptoms in Allergic Rhinitis: A Randomized Controlled Trial. Psychother. Psychosom. 2016, 85, 373-374. [CrossRef] [PubMed]

89. Kaptchuk, T.J.; Miller, F.G. Open label placebo: Can honestly prescribed placebos evoke meaningful therapeutic benefits? BMJ 2018, 363, k3889. [CrossRef] [PubMed]

90. Linden, M. Placebo: Unsolved Problems for Science, and Simple Conclusions for Clinical Practice. Am. J. Psychiatry 2017, 174, 91-92. [CrossRef] [PubMed]

91. Zilcha-Mano, S.; Brown, P.J.; Roose, S.P.; Cappetta, K.; Rutherford, B.R. Optimizing patient expectancy in the pharmacologic treatment of major depressive disorder. Psychol. Med. 2018. [CrossRef] [PubMed]

92. Faria, V.; Gingnell, M.; Hoppe, J.M.; Hjorth, O.; Alaie, I.; Frick, A.; Hultberg, S.; Wahlstedt, K.; Engman, J.; Mansson, K.N.T.; et al. Do You Believe It? Verbal Suggestions Influence the Clinical and Neural Effects of Escitalopram in Social Anxiety Disorder: A Randomized Trial. EBioMedicine 2017, 24, 179-188. [CrossRef]

93. Kirsch, I. Response Expectancy and the Response to Antidepressant Medication. EBioMedicine 2017, $25,13$. [CrossRef]

94. Leibowitz, K.A.; Hardebeck, E.J.; Goyer, J.P.; Crum, A.J. Physician Assurance Reduces Patient Symptoms in US Adults: An Experimental Study. J. Gen. Intern. Med. 2018. [CrossRef]

95. Evers, A.W.M.; Colloca, L.; Blease, C.; Annoni, M.; Atlas, L.Y.; Benedetti, F.; Bingel, U.; Buchel, C.; Carvalho, C.; Colagiuri, B.; et al. Implications of Placebo and Nocebo Effects for Clinical Practice: Expert Consensus. Psychother. Psychosom. 2018, 87, 204-210. [CrossRef]

96. Barraza, J.A.; Alexander, V.; Beavin, L.E.; Terris, E.T.; Zak, P.J. The heart of the story: Peripheral physiology during narrative exposure predicts charitable giving. Biol. Psychol. 2015, 105, 138-143. [CrossRef]

97. Zak, P.J. Why inspiring stories make us react: The neuroscience of narrative. Cerebrum 2015, $2015,2$. [PubMed]

98. Lin, P.Y.; Grewal, N.S.; Morin, C.; Johnson, W.D.; Zak, P.J. Oxytocin increases the influence of public service advertisements. PLoS ONE 2013, 8, e56934. [CrossRef] [PubMed]

99. Friesen, P.; Blease, C. Placebo effects and racial and ethnic health disparities: An unjust and underexplored connection. J. Med. Ethics 2018, 44, 774-781. [CrossRef] [PubMed]

100. Mercer, S.W.; Higgins, M.; Bikker, A.M.; Fitzpatrick, B.; McConnachie, A.; Lloyd, S.M.; Little, P.; Watt, G.C.M. General Practitioners' Empathy and Health Outcomes: A Prospective Observational Study of Consultations in Areas of High and Low Deprivation. Ann. Fam. Med. 2016, 14, 117-124. [CrossRef] [PubMed]

101. Jani, B.; Bikker, A.P.; Higgins, M.; Fitzpatrick, B.; Little, P.; Watt, G.C.M.; Mercer, S.W. Patient centredness and the outcome of primary care consultations with patients with depression in areas of high and low socioeconomic deprivation. Br. J. Gen. Pract. 2012, 62, e576-e581. [CrossRef] [PubMed]

102. Mercer, S.W.; Jani, B.D.; Maxwell, M.; Wong, S.Y.S.; Watt, G.C.M. Patient enablement requires physician empathy: A cross-sectional study of general practice consultations in areas of high and low socioeconomic deprivation in Scotland. BMC Fam. Pract. 2012, 13, 6. [CrossRef] [PubMed]

103. Ruberton, P.M.; Huynh, H.P.; Miller, T.A.; Kruse, E.; Chancellor, J.; Lyubomirsky, S. The relationship between physician humility, physician-patient communication, and patient health. Patient Educ. Couns. 2016, 99, 1138-1145. [CrossRef] [PubMed]

104. Saper, R. Integrative Medicine and Health Disparities. Glob. Adv. Health Med. 2016, 5, 5-8. [CrossRef] [PubMed]

105. Chao, M.T.; Adler, S.R. Integrative Medicine and the Imperative for Health Justice. J. Altern. Complement. Med. 2018, 24, 101-103. [CrossRef] [PubMed] 
106. Blasini, M.; Peiris, N.; Wright, T.; Colloca, L. The Role of Patient-Practitioner Relationships in Placebo and Nocebo Phenomena. Int. Rev. Neurobiol. 2018, 139, 211-231.

107. Geers, A.L.; Brinol, P.; Vogel, E.A.; Aspiras, O.; Caplandies, F.C.; Petty, R.E. The Application of Persuasion Theory to Placebo Effects. Int. Rev. Neurobiol. 2018, 138, 113-136. [PubMed]

108. Mack, J. Inventing a psychology of our relationship to the earth. In Psychology and Social Responsibility: Facing Global Challenges; Staub, S., Green, P., Eds.; NYU Press: New York, NY, USA, 1992; pp. $237-247$.

109. Albrecht, G.; Sartore, G.M.; Connor, L.; Higginbotham, N.; Freeman, S.; Kelly, B.; Stain, H.; Tonna, A.; Pollard, G. Solastalgia: The distress caused by environmental change. Aust. Psychiatry 2007, 15 (Suppl. 1), S95-S98. [CrossRef] [PubMed]

110. Logan, A.C.; Prescott, S.L.; Haahtela, T.; Katz, D.L. The importance of the exposome and allostatic load in the planetary health paradigm. J. Physiol. Anthropol. 2018, 37, 15. [CrossRef] [PubMed]

111. Colon, E.R. From fire escapes to qualitative data: Pedagogical urging, embodied research, and narrative medicine's ear of the heart. In The Principles and Practice of Narrative Medicine; Charon, R., Ed.; Oxford University Press: New York, NY, USA, 2017; pp. 252-266.

112. Charon, R. Narrative medicine: Form, function, and ethics. Ann. Intern. Med. 2001, 134, 83-87. [CrossRef] [PubMed]

113. Charon, R. Narrative and medicine. N. Engl. J. Med. 2004, 350, 862-864. [CrossRef]

114. Prescott, S.L.; Logan, A.C. From Authoritarianism to Advocacy: Lifestyle-Driven, Socially-Transmitted Conditions Require a Transformation in Medical Training and Practice. Challenges 2018, 9, 10. [CrossRef]

115. Davies, J. Political Pills: Psychopharmaceuticals and Neoliberalism as Mutually Supporting. In The Sedated Society. Springer International; Davies, L., Ed.; Gewerbestrasse: Cham, Switzerland, 2017; pp. 189-225.

116. Murphy, J.W.; Franz, B.A.; Choi, J.M.; Callaghan, K.A. The Politics of Storytelling. In Narrative Medicine and Community-Based Health Care and Planning; Springer: Cham, Switzerland, 2017; pp. 87-99.

117. Peek, M.E.; Wilson, S.C.; Bussey-Jones, J.; Lypson, M.; Cordasco, K.; Jacobs, E.A.; Bright, C.; Brown, A.F. A study of national physician organizations' efforts to reduce racial and ethnic health disparities in the United States. Acad. Med. 2012, 87, 694-700. [CrossRef]

118. Almutairi, A.F.; Dahinten, V.S. Construct Validity of Almutairi's Critical Cultural Competence Scale. West. J. Nurs. Res. 2017, 39, 784-802. [CrossRef]

119. Yeager, K.A.; Bauer-Wu, S. Cultural humility: Essential foundation for clinical researchers. Appl. Nurs. Res. 2013, 26, 251-256. [CrossRef]

120. Rajaram, S.S.; Bockrath, S. Cultural competence: New conceptual insights into its limits and potential for addressing health disparities. J. Health Disparities Res. Pract. 2014, 7, 82-89.

121. Rappaport, S.M. Genetic Factors Are Not the Major Causes of Chronic Diseases. PLoS ONE 2016, 11 , e0154387. [CrossRef] [PubMed]

122. Hood, C.M.; Gennuso, K.P.; Swain, G.R.; Catlin, B.B. County Health Rankings: Relationships Between Determinant Factors and Health Outcomes. Am. J. Prev. Med. 2016, 50, 129-135. [CrossRef] [PubMed]

123. Benatar, S.; Upshur, R.; Gill, S. Understanding the relationship between ethics, neoliberalism and power as a step towards improving the health of people and our planet. Anthropocene Rev. 2018, 5, 155-176. [CrossRef]

124. Fisher, J.A. Coming Soon to a Physician Near You: Medical Neoliberalism and Pharmaceutical Clinical Trials. Harvard Health Policy Rev. 2007, 8, 61-70. [PubMed]

125. Schram, A. When evidence isn't enough: Ideological, institutional, and interest-based constraints on achieving trade and health policy coherence. Glob. Soc. Pol. 2018, 18, 62-80. [CrossRef]

126. Ryu, K.; Lehto, X.Y.; Gordon, S.E.; Fu, X. Effect of brand story structure on narrative transportation and perceived brand image of luxury hotels. Tourism Manag. 2019, 71, 348-363. [CrossRef]

127. Dhar, R.; Wertenbroch, K. Consumer choice between hedonic and utilitarian goods. J. Mark. Res. 2000, 37, 60-71. [CrossRef]

128. Gill, S.; Benatar, S.R. History, Structure and Agency in Global Health Governance Comment on "Global Health Governance Challenges 2016-Are We Ready?". Int. J. Health Policy Manag. 2016, 6, 237-241. [CrossRef] [PubMed]

129. Cosgrove, L.; Karter, J.M. The poison in the cure: Neoliberalism and contemporary movements in mental health. Theor. Psychol. 2018, 28, 669-683. [CrossRef]

130. Sweet, E. "Like you failed at life": Debt, health and neoliberal subjectivity. Soc. Sci. Med. 2018, $212,86-93$. [CrossRef] [PubMed] 
131. Allen, L. Are we facing a noncommunicable disease pandemic? J. Epidemiol. Glob. Health 2017, 7, 5-9. [CrossRef] [PubMed]

132. Allen, L.N.; Feigl, A.B. What's in a name? A call to reframe non-communicable diseases. Lancet Glob. Health 2017, 5, e129-e130. [CrossRef]

133. Prescott, S.L.; Logan, A.C. Transforming Life: A Broad View of the Developmental Origins of Health and Disease Concept from an Ecological Justice Perspective. Int. J. Environ. Res. Public Health 2016, 13, 1075. [CrossRef] [PubMed]

134. Logan, A.C. Dysbiotic drift: Mental health, environmental grey space, and microbiota. J. Physiol. Anthropol. 2015, 34, 23. [CrossRef] [PubMed]

135. Wise, J. Britain's deprived areas have five times as many fast food shops as rich areas. BMJ 2018, $363, \mathrm{k} 4661$. [CrossRef]

136. Macdonald, L.; Olsen, J.R.; Shortt, N.K.; Ellaway, A. Do 'environmental bads' such as alcohol, fast food, tobacco, and gambling outlets cluster and co-locate in more deprived areas in Glasgow City, Scotland? Health Place 2018, 51, 224-231. [CrossRef] [PubMed]

137. Tan, P.J.; Corsi, A.; Cohen, J.; Sharp, A.; Lockshin, L.; Caruso, W.; Bogomolova, S. Assessing the sales effectiveness of differently located endcaps in a supermarket. J. Retail. Consum. Serv. 2018, 43, 200-208. [CrossRef]

138. Ribisl, K.M.; D'Angelo, H.; Feld, A.L.; Schleicher, N.C.; Golden, S.; Luke, D.A.; Henriksen, L. Disparities in tobacco marketing and product availability at the point of sale: Results of a national study. Prev. Med. 2017. [CrossRef]

139. Moodie, R.; Stuckler, D.; Monteiro, C.; Sheron, N.; Neal, B.; Thamarangsi, T.; Lincoln, P.; Casswell, S.; Lancet, N.C.D.A.G. Profits and pandemics: Prevention of harmful effects of tobacco, alcohol, and ultra-processed food and drink industries. Lancet 2013, 381, 670-679. [CrossRef]

140. Moodie, A.R. What Public Health Practitioners Need to Know About Unhealthy Industry Tactics. Am. J. Public Health 2017, 107, 1047-1049. [CrossRef]

141. Clapp, J.; Scrinis, G. Big Food, Nutritionism, and Corporate Power. Globalizations 2017, 14, 578-595. [CrossRef]

142. Petticrew, M.; McKee, M.; Marteau, T.M. Partnerships with the alcohol industry at the expense of public health. Lancet 2018, 392, 992-993. [CrossRef]

143. Daube, M.; Moodie, R.; McKee, M. Towards a smoke-free world? Philip Morris International's new Foundation is not credible. Lancet 2017, 390, 1722-1724. [CrossRef]

144. Leon, K.S.; Ken, I. Legitimized fraud and the state-corporate criminology of food-A Spectrum-based theory. Crime Law Soc. Chang. 2018, 71, 25-46. [CrossRef]

145. Prescott, S.L.; Wegienka, G.; Logan, A.C.; Katz, D.L. Dysbiotic drift and biopsychosocial medicine: How the microbiome links personal, public and planetary health. Biopsychosoc. Med. 2018, 12, 7. [CrossRef] [PubMed]

146. McKee, M.; Stuckler, D. Revisiting the Corporate and Commercial Determinants of Health. Am. J. Public Health 2018, 108, 1167-1170. [CrossRef] [PubMed]

147. Kroll, A.; Schulman, J. Leaked Documents Reveal the Secret Finances of a Pro-Industry Science Group. 2013. Available online: https:/ /www.motherjones.com/politics/2013/10/american-council-science-healthleaked-documents-fundraising/ (accessed on 6 December 2018).

148. Editors. The burger that conquered the country. Time 1973, 102, 84-92.

149. Severson, K. Los Angeles Stages a Fast Food Intervention. Available online: https:/ /www.nytimes.com/ 2008/08/13/dining/13calo.html (accessed on 6 December 2018).

150. Lagstrom, H.; Halonen, J.I.; Kawachi, I.; Stenholm, S.; Pentti, J.; Suominen, S.; Kivimaki, M.; Vahtera, J. Neighborhood socioeconomic status and adherence to dietary recommendations among Finnish adults: A retrospective follow-up study. Health Place 2018. [CrossRef]

151. Zagorsky, J.L.; Smith, P.K. The association between socioeconomic status and adult fast-food consumption in the U.S. Econ. Hum. Biol. 2017, 27, 12-25. [CrossRef]

152. Di Renzo, L.; Merra, G.; Botta, R.; Gualtieri, P.; Manzo, A.; Perrone, M.A.; Mazza, M.; Cascapera, S.; De Lorenzo, A. Post-prandial effects of hazelnut-enriched high fat meal on LDL oxidative status, oxidative and inflammatory gene expression of healthy subjects: A randomized trial. Eur. Rev. Med. Pharmacol. Sci. 2017, 21, 1610-1626. 
153. Ng, C.K.; Chan, A.P.; Cheng, A. Impairment of endothelial function-A possible mechanism for atherosclerosis of a high-fat meal intake. Ann. Acad. Med. 2001, 30, 499-502.

154. Uribarri, J.; Woodruff, S.; Goodman, S.; Cai, W.; Chen, X.; Pyzik, R.; Yong, A.; Striker, G.E.; Vlassara, H. Advanced glycation end products in foods and a practical guide to their reduction in the diet. J. Am. Diet. Assoc. 2010, 110, 911-916. [CrossRef] [PubMed]

155. Stirban, A.; Gawlowski, T.; Roden, M. Vascular effects of advanced glycation endproducts: Clinical effects and molecular mechanisms. Mol. Metab. 2014, 3, 94-108. [CrossRef] [PubMed]

156. Emerson, S.R.; Kurti, S.P.; Harms, C.A.; Haub, M.D.; Melgarejo, T.; Logan, C.; Rosenkranz, S.K. Magnitude and Timing of the Postprandial Inflammatory Response to a High-Fat Meal in Healthy Adults: A Systematic Review. Adv. Nutr. 2017, 8, 213-225. [CrossRef] [PubMed]

157. Benson, T.W.; Weintraub, N.L.; Kim, H.W.; Seigler, N.; Kumar, S.; Pye, J.; Horimatsu, T.; Pellenberg, R.; Stepp, D.W.; Lucas, R.; et al. A single high-fat meal provokes pathological erythrocyte remodeling and increases myeloperoxidase levels: Implications for acute coronary syndrome. Lab. Investig. 2018, 98, 1300-1310. [CrossRef] [PubMed]

158. Prescott, S.L.; Logan, A.C. Each meal matters in the exposome: Biological and community considerations in fast-food-socioeconomic associations. Econ. Hum. Biol. 2017, 27, 328-335. [CrossRef]

159. Ganji, V.; Kafai, M.R.; Third National, H.; Nutrition Examination, S. Population determinants of serum lycopene concentrations in the United States: Data from the Third National Health and Nutrition Examination Survey, 1988-1994. J. Nutr. 2005, 135, 567-572. [CrossRef]

160. Nicklett, E.J.; Szanton, S.; Sun, K.; Ferrucci, L.; Fried, L.P.; Guralnik, J.M.; Semba, R.D. Neighborhood socioeconomic status is associated with serum carotenoid concentrations in older, community-dwelling women. J. Nutr. 2011, 141, 284-289. [CrossRef]

161. Janicki-Deverts, D.; Cohen, S.; Matthews, K.A.; Gross, M.D.; Jacobs, D.R., Jr. Socioeconomic status, antioxidant micronutrients, and correlates of oxidative damage: The Coronary Artery Risk Development in Young Adults (CARDIA) study. Psychosom. Med. 2009, 71, 541-548. [CrossRef]

162. Kristenson, M.; Kucinskiene, Z.; Bergdahl, B.; Orth-Gomer, K. Risk factors for coronary heart disease in different socioeconomic groups of Lithuania and Sweden-the LiVicordia Study. Scand. J. Public Health 2001, 29, 140-150. [CrossRef]

163. Stimpson, J.P.; Nash, A.C.; Ju, H.; Eschbach, K. Neighborhood Deprivation is associated with lower levels of serum carotenoids among adults participating in the Third National Health and Nutrition Examination Survey. J. Am. Diet. Assoc. 2007, 107, 1895-1902. [CrossRef] [PubMed]

164. Shohaimi, S.; Bingham, S.; Welch, A.; Luben, R.; Day, N.; Wareham, N.; Khaw, K.T. Occupational social class, educational level and area deprivation independently predict plasma ascorbic acid concentration: A cross-sectional population based study in the Norfolk cohort of the European Prospective Investigation into Cancer (EPIC-Norfolk). Eur. J. Clin. Nutr. 2004, 58, 1432-1435. [CrossRef] [PubMed]

165. Wrieden, W.L.; Hannah, M.K.; Bolton-Smith, C.; Tavendale, R.; Morrison, C.; Tunstall-Pedoe, H. Plasma vitamin $\mathrm{C}$ and food choice in the third Glasgow MONICA population survey. J. Epidemiol. Community Health 2000, 54, 355-360. [CrossRef] [PubMed]

166. Esposito, K.; Ciotola, M.; Sasso, F.C.; Cozzolino, D.; Saccomanno, F.; Assaloni, R.; Ceriello, A.; Giugliano, D. Effect of a single high-fat meal on endothelial function in patients with the metabolic syndrome: Role of tumor necrosis factor-alpha. Nutr. Metab. Cardiovasc. Dis. 2007, 17, 274-279. [CrossRef] [PubMed]

167. Jantzi, P.S.; Marangoni, A.G.; Idziak, S.H.J.; Rush, J. Markers of Cardiovascular Risk and Metabolism Assessed on Multiple Baseline Occasions and in Response to a Single Fatty Meal in Healthy Young Adults. Food Dig. 2013, 4, 49. [CrossRef]

168. Kardinaal, A.F.; van Erk, M.J.; Dutman, A.E.; Stroeve, J.H.; van de Steeg, E.; Bijlsma, S.; Kooistra, T.; van Ommen, B.; Wopereis, S. Quantifying phenotypic flexibility as the response to a high-fat challenge test in different states of metabolic health. FASEB J. 2015, 29, 4600-4613. [CrossRef] [PubMed]

169. Bird, C.E.; Seeman, T.; Escarce, J.J.; Basurto-Davila, R.; Finch, B.K.; Dubowitz, T.; Heron, M.; Hale, L.; Merkin, S.S.; Weden, M.; et al. Neighbourhood socioeconomic status and biological 'wear and tear' in a nationally representative sample of US adults. J. Epidemiol. Community Health 2010, 64, 860-865. [CrossRef]

170. Prior, L.; Manley, D.; Jones, K. Stressed out? An investigation of whether allostatic load mediates associations between neighbourhood deprivation and health. Health Place 2018, 52, 25-33. [CrossRef] 
171. Brody, G.H.; Lei, M.K.; Chen, E.; Miller, G.E. Neighborhood Poverty and Allostatic Load in African American Youth. Pediatrics 2014, 134, E1362-E1368. [CrossRef]

172. Miller, G.E.; Engen, P.A.; Gillevet, P.M.; Shaikh, M.; Sikaroodi, M.; Forsyth, C.B.; Mutlu, E.; Keshavarzian, A. Lower Neighborhood Socioeconomic Status Associated with Reduced Diversity of the Colonic Microbiota in Healthy Adults. PLoS ONE 2016, 11, e0148952. [CrossRef]

173. Marshall, N.A.; Marusak, H.A.; Sala-Hamrick, K.J.; Crespo, L.M.; Rabinak, C.A.; Thomason, M.E. Socioeconomic disadvantage and altered corticostriatal circuitry in urban youth. Hum. Brain Mapp. 2018, 39, 1982-1994. [CrossRef] [PubMed]

174. Gianaros, P.J.; Kuan, D.C.; Marsland, A.L.; Sheu, L.K.; Hackman, D.A.; Miller, K.G.; Manuck, S.B. Community Socioeconomic Disadvantage in Midlife Relates to Cortical Morphology via Neuroendocrine and Cardiometabolic Pathways. Cereb. Cortex 2017, 27, 460-473. [CrossRef] [PubMed]

175. Kiecolt-Glaser, J.K.; Fagundes, C.P.; Andridge, R.; Peng, J.; Malarkey, W.B.; Habash, D.; Belury, M.A. Depression, daily stressors and inflammatory responses to high-fat meals: When stress overrides healthier food choices. Mol. Psychiatry 2017, 22, 476-482. [CrossRef] [PubMed]

176. Lindsay, K.L.; Buss, C.; Wadhwa, P.D.; Entringer, S. Maternal Stress Potentiates the Effect of an Inflammatory Diet in Pregnancy on Maternal Concentrations of Tumor Necrosis Factor Alpha. Nutrients 2018, 10, 1252. [CrossRef] [PubMed]

177. Cheon, B.K.; Hong, Y.Y. Mere experience of low subjective socioeconomic status stimulates appetite and food intake. Proc. Natl. Acad. Sci. USA 2017, 114, 72-77. [CrossRef] [PubMed]

178. Sim, A.Y.; Lim, E.X.; Forde, C.G.; Cheon, B.K. Personal relative deprivation increases self-selected portion sizes and food intake. Appetite 2018, 121, 268-274. [CrossRef] [PubMed]

179. Wijayatunga, N.N.; Ironuma, B.; Dawson, J.A.; Rusinovich, B.; Myers, C.A.; Cardel, M.; Pavela, G.; Martin, C.K.; Allison, D.B.; Dhurandhar, E.J. Subjective social status is associated with compensation for large meals - A prospective pilot study. Appetite 2019, 132, 249-256. [CrossRef]

180. Cardel, M.I.; Johnson, S.L.; Beck, J.; Dhurandhar, E.; Keita, A.D.; Tomczik, A.C.; Pavela, G.; Huo, T.; Janicke, D.M.; Muller, K.; et al. The effects of experimentally manipulated social status on acute eating behavior: A randomized, crossover pilot study. Physiol. Behav. 2016, 162, 93-101. [CrossRef]

181. Bratanova, B.; Loughnan, S.; Klein, O.; Claassen, A.; Wood, R. Poverty, inequality, and increased consumption of high calorie food: Experimental evidence for a causal link. Appetite 2016, 100, 162-171. [CrossRef]

182. Sim, A.Y.; Lim, E.X.; Leow, M.K.; Cheon, B.K. Low subjective socioeconomic status stimulates orexigenic hormone ghrelin-A randomised trial. Psychoneuroendocrinology 2018, 89, 103-112. [CrossRef]

183. Yousufzai, M.; Harmatz, E.S.; Shah, M.; Malik, M.O.; Goosens, K.A. Ghrelin is a persistent biomarker for chronic stress exposure in adolescent rats and humans. Transl. Psychiatry 2018, 8, 74. [CrossRef]

184. Sztainert, T.; Hay, R.; Wohl, M.J.A.; Abizaid, A. Hungry to gamble? Ghrelin as a predictor of persistent gambling in the face of loss. Biol. Psychol. 2018, 139, 115-123. [CrossRef] [PubMed]

185. Forshee, R.A.; Storey, M.L. Demographics, not beverage consumption, is associated with diet quality. Int. J. Food Sci. Nutr. 2006, 57, 494-511. [CrossRef] [PubMed]

186. Baraldi, L.G.; Martinez Steele, E.; Canella, D.S.; Monteiro, C.A. Consumption of ultra-processed foods and associated sociodemographic factors in the USA between 2007 and 2012: Evidence from a nationally representative cross-sectional study. BMJ Open 2018, 8, e020574. [CrossRef] [PubMed]

187. Lee-Kwan, S.H.; Moore, L.V.; Blanck, H.M.; Harris, D.M.; Galuska, D. Disparities in State-Specific Adult Fruit and Vegetable Consumption-United States, 2015. Morb. Mortal. Wkly. Rep. 2017, 66, 1241-1247. [CrossRef] [PubMed]

188. Giurgescu, C.; Engeland, C.G.; Templin, T.N.; Zenk, S.N.; Koenig, M.D.; Garfield, L. Racial discrimination predicts greater systemic inflammation in pregnant African American women. Appl. Nurs. Res. 2016, 32, 98-103. [CrossRef]

189. Beatty, D.L.; Matthews, K.A.; Bromberger, J.T.; Brown, C. Everyday Discrimination Prospectively Predicts Inflammation Across 7-Years in Racially Diverse Midlife Women: Study of Women's Health Across the Nation. J. Soc. Issues 2014, 70, 298-314. [CrossRef]

190. Lewis, T.T.; Aiello, A.E.; Leurgans, S.; Kelly, J.; Barnes, L.L. Self-reported experiences of everyday discrimination are associated with elevated C-reactive protein levels in older African-American adults. Brain Behav. Immunity 2010, 24, 438-443. [CrossRef] 
191. Saban, K.L.; Mathews, H.L.; Bryant, F.B.; Tell, D.; Joyce, C.; DeVon, H.A.; Witek Janusek, L. Perceived discrimination is associated with the inflammatory response to acute laboratory stress in women at risk for cardiovascular disease. Brain Behav. Immunity 2018, 73, 625-632. [CrossRef]

192. Hinz, A.; Sander, C.; Glaesmer, H.; Brahler, E.; Zenger, M.; Hilbert, A.; Kocalevent, R.D. Optimism and pessimism in the general population: Psychometric properties of the Life Orientation Test (LOT-R). Int. J. Clin. Health Psychol. 2017, 17, 161-170. [CrossRef]

193. Boehm, J.K.; Chen, Y.; Williams, D.R.; Ryff, C.; Kubzansky, L.D. Unequally distributed psychological assets: Are there social disparities in optimism, life satisfaction, and positive affect? PLoS ONE 2015, 10, e0118066. [CrossRef] [PubMed]

194. Kim, E.S.; Hagan, K.A.; Grodstein, F.; DeMeo, D.L.; De Vivo, I.; Kubzansky, L.D. Optimism and Cause-Specific Mortality: A Prospective Cohort Study. Am. J. Epidemiol. 2017, 185, 21-29. [CrossRef] [PubMed]

195. Bouchard, L.C.; Carver, C.S.; Mens, M.G.; Scheier, M.F. Optimism, Health, and Wellbeing. In Positive Psychology: Established and Emerging Issues; Dunn, D.S., Ed.; Routledge: New York, NY, USA, 2018; Section 8.

196. Roy, B.; Diez-Roux, A.V.; Seeman, T.; Ranjit, N.; Shea, S.; Cushman, M. Association of optimism and pessimism with inflammation and hemostasis in the Multi-Ethnic Study of Atherosclerosis (MESA). Psychosom. Med. 2010, 72, 134-140. [CrossRef] [PubMed]

197. Romswinkel, E.V.; Konig, H.H.; Hajek, A. The role of optimism in the relationship between job stress and depressive symptoms. Longitudinal findings from the German Ageing Survey. J. Affect. Disord. 2018, 241, 249-255. [CrossRef]

198. Bajaj, A.; Bronson, C.A.; Habel, M.; Rahman, S.; Weisberg, H.R.; Contrada, R.J. Dispositional Optimism and Cardiovascular Reactivity Accompanying Anger and Sadness in Young Adults. Ann. Behav. Med. 2018. [CrossRef]

199. Brydon, L.; Walker, C.; Wawrzyniak, A.J.; Chart, H.; Steptoe, A. Dispositional optimism and stress-induced changes in immunity and negative mood. Brain Behav. Immunity 2009, 23, 810-816. [CrossRef]

200. Daniel, T.O.; Said, M.; Stanton, C.M.; Epstein, L.H. Episodic future thinking reduces delay discounting and energy intake in children. Eat. Behav. 2015, 18, 20-24. [CrossRef]

201. Daniel, T.O.; Stanton, C.M.; Epstein, L.H. The future is now: Comparing the effect of episodic future thinking on impulsivity in lean and obese individuals. Appetite 2013, 71, 120-125. [CrossRef]

202. Mellis, A.M.; Snider, S.E.; Bickel, W.K. Narrative theory: II. Self-generated and experimenter-provided negative income shock narratives increase delay discounting. Exp. Clin. Psychopharmacol. 2018, 26, 113-118. [CrossRef]

203. Ishii, K. Subjective socioeconomic status and cigarette smoking interact to delay discounting. Springerplus 2015, 4, 560. [CrossRef]

204. Lovallo, W.R.; Farag, N.H.; Sorocco, K.H.; Acheson, A.; Cohoon, A.J.; Vincent, A.S. Early Life Adversity Contributes to Impaired Cognition and Impulsive Behavior: Studies from the Oklahoma Family Health Patterns Project. Alcohol. Clin. Exp. Res. 2013, 37, 616-623. [CrossRef] [PubMed]

205. Acheson, A.; Vincent, A.S.; Sorocco, K.H.; Lovallo, W.R. Greater Discounting of Delayed Rewards in Young Adults with Family Histories of Alcohol and Drug Use Disorders: Studies from the Oklahoma Family Health Patterns Project. Alcohol. Clin. Exp. Res. 2011, 35, 1607-1613. [CrossRef] [PubMed]

206. Joireman, J.; King, S. Individual Differences in the Consideration of Future and (More) Immediate Consequences: A Review and Directions for Future Research. Soc. Personal. Psychol. 2016, 10, 313-326. [CrossRef]

207. DeVoe, S.E.; House, J.; Zhong, C.B. Fast food and financial impatience: A socioecological approach. J. Pers. Soc. Psychol. 2013, 105, 476-494. [CrossRef] [PubMed]

208. House, J.; DeVoe, S.E.; Zhong, C.B. Too impatient to smell the roses: Exposure to fast food impedes happiness. Soc. Psychol. Personal. Sci. 2014, 5, 534-541. [CrossRef]

209. Van der Wal, A.J.; Schade, H.M.; Krabbendam, L.; van Vugt, M. Do natural landscapes reduce future discounting in humans? Proc. R. Soc. B-Biol. Sci. 2013, 280. [CrossRef]

210. Berry, M.S.; Sweeney, M.M.; Morath, J.; Odum, A.L.; Jordan, K.E. The Nature of Impulsivity: Visual Exposure to Natural Environments Decreases Impulsive Decision-Making in a Delay Discounting Task. PLoS ONE 2014, 9, e11554. [CrossRef] 
211. Berry, M.S.; Repke, M.A.; Nickerson, N.P.; Conway, L.G.; Odum, A.L.; Jordan, K.E. Making Time for Nature: Visual Exposure to Natural Environments Lengthens Subjective Time Perception and Reduces Impulsivity. PLoS ONE 2015, 10, e0141030. [CrossRef]

212. Van Dyke, M.E.; Komro, K.A.; Shah, M.P.; Livingston, M.D.; Kramer, M.R. State-level minimum wage and heart disease death rates in the United States, 1980-2015: A novel application of marginal structural modeling. Prev. Med. 2018, 112, 97-103. [CrossRef]

213. Lenhart, O. Do Higher Minimum Wages Benefit Health? Evidence From the UK. J. Policy Anal. Manag. 2017, 36, 828-852. [CrossRef]

214. Lenhart, O. The impact of minimum wages on population health: Evidence from 24 OECD countries. Eur. J. Health Econ. 2016. [CrossRef] [PubMed]

215. Reeves, A.; McKee, M.; Mackenbach, J.; Whitehead, M.; Stuckler, D. Introduction of a National Minimum Wage Reduced Depressive Symptoms in Low-Wage Workers: A Quasi-Natural Experiment in the UK. Health Econ. 2016. [CrossRef] [PubMed]

216. Burmaster, K.B.; Landefeld, J.C.; Rehkopf, D.H.; Lahiff, M.; Sokal-Gutierrez, K.; Adler-Milstein, S.; Fernald, L.C. Impact of a private sector living wage intervention on depressive symptoms among apparel workers in the Dominican Republic: A quasi-experimental study. BMJ Open 2015, 5, e007336. [PubMed]

217. Reeves, A.; Loopstra, R.; Stuckler, D. The growing disconnect between food prices and wages in Europe: Cross-national analysis of food deprivation and welfare regimes in twenty-one EU countries, 2004-2012. Public Health Nutr. 2017, 20, 1414-1422. [CrossRef] [PubMed]

218. Du, J.; Leigh, J.P. Effects of Minimum Wages on Absence from Work Due to Illness. J. Econ. Anal. Policy 2017, 18. [CrossRef]

219. Ponce, N.; Shimkhada, R.; Raub, A.; Daoud, A.; Nandi, A.; Richter, L.; Heymann, J. The association of minimum wage change on child nutritional status in LMICs: A quasi-experimental multi-country study. Glob. Public Health 2017, 2, 1-15. [CrossRef]

220. Pohl, R.; Clark, K.; Thomas, R. Minimum Wages and Healthy Diet. Available online: http:/ / dx.doi.org/10. 2139/ssrn.2892894 (accessed on 2 January 2017).

221. Michimi, A.; Wimberly, M.C. The food environment and adult obesity in US metropolitan areas. Geospat. Health 2015, 10, 368. [CrossRef]

222. Dickman, S.L.; Himmelstein, D.U.; Woolhandler, S. Inequality and the health-care system in the USA. Lancet 2017, 389, 1431-1441. [CrossRef]

223. Charon, R. Narrative medicine: Caring for the sick is a work of art. JAAPA 2013, 26, 8. [CrossRef]

224. Greer, S.L.; Bekker, M.; de Leeuw, E.; Wismar, M.; Helderman, J.K.; Ribeiro, S.; Stuckler, D. Policy, politics and public health. Eur. J. Public Health 2017, 27, 40-43. [CrossRef]

225. Glasgow, S.; Schrecker, T. The double burden of neoliberalism? Noncommunicable disease policies and the global political economy of risk. Health Place 2016, 39, 204-211. [CrossRef] [PubMed]

226. McKee, M.; Stuckler, D. “Enemies of the People?" Public Health in the Era of Populist Politics Comment on "The Rise of Post-truth Populism in Pluralist Liberal Democracies: Challenges for Health Policy". Int. J. Health Policy Manag. 2017, 6, 669-672. [CrossRef] [PubMed]

227. Purtle, J.; Goldstein, N.D.; Edson, E.; Hand, A. Who votes for public health? U.S. senator characteristics associated with voting in concordance with public health policy recommendations (1998-2013). SSM Popul. Health 2017, 3, 136-140. [CrossRef] [PubMed]

228. Grande, D.; Asch, D.A.; Armstrong, K. Do doctors vote? J. Gen. Intern. Med. 2007, 22, 585-589. [CrossRef] [PubMed]

229. Grande, D.; Armstrong, K. Community volunteerism of US physicians. J. Gen. Intern. Med. 2008, 23, 1987-1991. [CrossRef] [PubMed]

230. Logan, A.C.; Prescott, S.L. Astrofood, priorities and pandemics: Reflections of an ultra-processed breakfast program and contemporary dysbiotic drift. Challenges 2017, 8, 24. [CrossRef]

231. Bryan, C.J.; Yeager, D.S.; Hinojosa, C.P.; Chabot, A.; Bergen, H.; Kawamura, M.; Steubing, F. Harnessing adolescent values to motivate healthier eating. Proc. Natl. Acad. Sci. USA 2016, 113, 10830-10835. [CrossRef] [PubMed]

232. Thompson, B.; Molina, Y.; Viswanath, K.; Warnecke, R.; Prelip, M.L. Strategies To Empower Communities To Reduce Health Disparities. Health Aff. 2016, 35, 1424-1628. [CrossRef]

233. Gardner, C.D.; Hauser, M.E. Food revolution. Am. J. Lifestyle Med. 2017, 8, 387-396. [CrossRef] 
234. Yeager, D.S.; Dahl, R.E.; Dweck, C.S. Why Interventions to Influence Adolescent Behavior Often Fail but Could Succeed. Perspect. Psychol. Sci. 2018, 13, 101-122. [CrossRef]

235. Zhong, Y.; Auchincloss, A.H.; Lee, B.K.; Kanter, G.P. The Short-Term Impacts of the Philadelphia Beverage Tax on Beverage Consumption. Am. J. Prev. Med. 2018, 55, 26-34. [CrossRef] [PubMed]

236. Roache, S.A.; Gostin, L.O. The Untapped Power of Soda Taxes: Incentivizing Consumers, Generating Revenue, and Altering Corporate Behavior. Int. J. Health Policy Manag. 2017, 6, 489-493. [CrossRef] [PubMed]

237. Bonaccio, M.; Di Castelnuovo, A.; Pounis, G.; Costanzo, S.; Persichillo, M.; Cerletti, C.; Donati, M.B.; de Gaetano, G.; Iacoviello, L.; Investigators, M.-S.P. High adherence to the Mediterranean diet is associated with cardiovascular protection in higher but not in lower socioeconomic groups: Prospective findings from the Moli-sani study. Int. J. Epidemiol. 2017, 46, 1478-1487. [CrossRef] [PubMed]

238. Cavaliere, A.; De Marchi, E.; Banterle, A. Exploring the Adherence to the Mediterranean Diet and Its Relationship with Individual Lifestyle: The Role of Healthy Behaviors, Pro-Environmental Behaviors, Income, and Education. Nutrients 2018, 10, 141. [CrossRef] [PubMed]

239. Da Costa, P.N. More Americans Need a 2nd Job to Make Ends Meet-And It's Sending a Troubling Message About the Economy. Available online: https://www.businessinsider.com.au/more-americans-workingmore-than-one-job-to-make-ends-meet-2017-8 (accessed on 6 December 2018).

240. Haar, J.; Carr, S.C.; Arrowsmith, J.; Parker, J.; Hodgetts, D.; Alefaio-Tugia, S. Escape from Working Poverty: Steps toward Sustainable Livelihood. Sustainability 2018, 10, 4144. [CrossRef]

241. Crouse, D.L.; Pinault, L.; Balram, A.; Hystad, P.; Peters, P.A.; Chen, H.; van Donkelaar, A.; Martin, R.V.; Menard, R.; Robichaud, A.; et al. Urban greenness and mortality in Canada's largest cities: A national cohort study. Lancet Planet. Health 2017, 1, e289-e297. [CrossRef]

242. Carr, S.C.; Maleka, M.; Meyer, I.; Barry, M.L.; Haar, J.; Parker, J.; Arrowsmith, J.; Yao, C.; Hodgetts, D.; Jones, H.; et al. How can wages sustain a living? By getting ahead of the curve. Sustain. Sci. 2018, 13, 901-917. [CrossRef]

243. Falls, B. My Personal Hell. In Critical Storytelling in Uncritical Times. Constructing Knowledge: Curriculum Studies In Action; Hartlep, N.D., Hensley, B.O., Braniger, C.J., Jennings, M.E., Eds.; SensePublishers: Rotterdam, The Netherlands, 2017.

244. Swanberg, J.E.; Nichols, H.M.; Ko, J.; Tracy, J.K.; Vanderpool, R.C. Managing cancer and employment: Decisions and strategies used by breast cancer survivors employed in low-wage jobs. J. Psychosoc. Oncol. 2017, 35, 180-201. [CrossRef]

245. Norris, P.; Tordoff, J.; McIntosh, B.; Laxman, K.; Chang, S.Y.; Te Karu, L. Impact of prescription charges on people living in poverty: A qualitative study. Res. Soc. Adm. Pharm. 2016, 12, 893-902. [CrossRef]

246. Simons, A.M.W.; Houkes, I.; Koster, A.; Groffen, D.A.I.; Bosma, H. The silent burden of stigmatisation: A qualitative study among Dutch people with a low socioeconomic position. BMC Public Health 2018, 18, 443. [CrossRef]

247. Cunsolo, A.; Ellis, N.R. Ecological grief as a mental health response to climate change-related loss. Nat. Clim. Chang. 2018, 8, 275-281. [CrossRef]

248. Jones, J.; Cunsolo, A.; Harper, S.L. Who is research serving? A systematic realist review of circumpolar environment-related Indigenous health literature. PLoS ONE 2018, 13, e0196090. [CrossRef] [PubMed]

249. Sapir, E. The Status of Linguistics as a Science (vol 5, pg 207, 1929). Collect. Works Edward Sapir I 2008, 219-226. [CrossRef]

250. Whorf, B.L. Science and linguistics. Tech. Rev. 1940, 42, 229-231.

251. Lekhtsier, V.; Gotlib, A. Narrative medicine in the framework of empirical social research: The Russian context. Salud Colect. 2017, 13, 239-252. [CrossRef] [PubMed]

252. McKee, M.; Reeves, A.; Clair, A.; Stuckler, D. Living on the edge: Precariousness and why it matters for health. Arch. Public Health 2017, 75, 13. [CrossRef] [PubMed]

253. Carroll, T.; Gonzalez-Vicente, R. From New Deal to the Art of the Deal: How the Neoliberal Project Led to Trump. Available online: https:/ theconversation.com/from-new-deal-to-the-art-of-the-deal-how-theneoliberal-project-led-to-trump-71576 (accessed on 6 December 2018).

254. Dubos, R. Man Overadapting. Psychol. Today 1971, 4, 5-53.

(C) 2019 by the authors. Licensee MDPI, Basel, Switzerland. This article is an open access article distributed under the terms and conditions of the Creative Commons Attribution (CC BY) license (http:/ / creativecommons.org/licenses/by/4.0/). 